\title{
"SUBSTANCE" vs. "FORM" IN THE APPLICATION OF THE COMMERCE CLAUSE TO STATE TAXATION
}

\author{
Edward L. Barrett, Jr. $†$
}

Prior to 1938 the United States Supreme Court decisions dealing with both state regulation and state taxation of interstate commerce (in the absence of Congressional action) were phrased in terms of a purely formal test: Direct burdens upon interstate commerce were forbidden. Indirect or remote restraints were permitted. ${ }^{1}$ Subsequent development in the regulation field has been completely away from the direct burden approach. Today the Supreme Court recognizes that the problem is one of balancing national versus local interests. It seeks to determine the extent to which the regulation actually interferes with the free flow of commerce. It examines carefully the local interest involved and the extent to which the challenged regulation serves that interest. On the basis of such factual investigations it decides whether the national interest in the free flow of commerce is outweighed by the local interest which gave rise to the regulation. ${ }^{2}$

In state taxation cases, however, the Supreme Court is still deciding many cases in terms of the formal incidence of the particular tax involved with but little regard for its substantive effect upon interstate

$\div$ Professor of Law, University of California at Berkeley, School of Law.

1. See, e.g., Seaboard Air Line Ry. v. Blackwell, 244 U.S. 310 (1917) ; Di Santo v. Pennsylvania, 273 U.S. 34 (1927) ; Minnesota v. Blasius, 290 U.S. 1 (1933). In Minnesota v. Blasins, a tax case, the Court said: "The States may not impose direct burdens upon interstate commerce, that is, they may not regulate or restrain that which from its nature should be under the control of the one authority and be free from restriction save as it is governed in the manner that the national legislature constitutionally ordains. This limitation applies to the exertion of the State's taxing power as well as to any other interference by the State with the essential freedom of interstate commerce." Id. at 8.

Substantive considerations often controlled decisions, of course, even though opinions were written in terms of the direct burden test. See, e.g., Seaboard Air Line Ry. v. Blackwell, sipra; Baldwin v. G.A.F. Seelig, Inc., 294 U.S. 511 (1935).

2. "It is now well settled that a state may regulate matters of local concern over which federal authority has not been exercised, even though the regulation has some impact on interstate commerce. . . The only requirements consistently recognized have been that the regulation not discriminate against or place an embargo on interstate commerce, that it safeguard an obvious state interest, and that the local interest at stake outweigh whatever national interest there might be in the prevention of state restrictions." Cities Service Gas Co. v. Peerless Oil \& Gas Co., 340 U.S. 179, 186 (1950). See also Southern Pacific Co. v. Arizona, 325 U.S. 761 (1945); Dean Milk Co. v. City of Madison, 340 U.S. 349 (1951). But cf. H. P. Hood \& Sons v. Du Mond, Inc., 336 U.S. 525 (1949) (a reversion, seemingly temporary, to more formal standards). 
commerce. A state may not be allowed "one single-tax-worth of direct interference with the free flow of commerce." 3 The objection to the validity of a tax "does not rest on a claim that it places an unduly heavy burden on interstate commerce in return for protection given by the State" but upon the fact that it is "placed unequivocally upon the corporation's franchise for the privilege of carrying on exclusively interstate transportation in the State." 4 A tax "imposed upon the privilege of soliciting interstate business" stands "on no better footing than a tax upon the privilege of doing interstate business." 5

For a time it seemed that there would be somewhat parallel developments in the regulation and tax cases. ${ }^{6}$ From Western Live Stock v. Bureau of Revenue ${ }^{7}$ in 1938 through McGoldrick v. BerwindWhite Coal Mining Co. ${ }^{8}$ in $1940 \mathrm{Mr}$. Justice Stone appeared to be leading the Court (with his famous "multiple burdens" test) toward the adoption of substantive criteria as the basis for decision. McLeod v. J. E. Dilworth $\mathrm{Co}^{\circ}{ }^{\circ}$ in 1944 heralded a return to formal considera-

3. Freeman v. Hewit, 329 U.S. 249, 256 (1946).

4. Spector Motor Service, Inc. v. O'Connor, 340 U.S. 602,607 (1951).

5. Memphis Steam Laundry Cleaner, Inc. v. Stone, 342 U.S. 389, 393 (1952).

6. The cases prior to 1951 were discussed in detail by the author in Barrett, State Taxation of Interstate Commerce- "Direct Burdens," "Multiple Burdens," or What Have You?, 4 VAND. L. REv. 496 (1951). Reference is made to that article for elaboration of the matters touched upon in this paragraph of the text. See also Sabine, Interstate Commerce and State Taxation In The Supreme Court; 1950 Term, 26 J. St. Bar CaIIF. 347 (1951).

7. 303 U.S. 250 (1938). In this case Justice Stone first discussed the "multiple burden" doctrine as applied to gross receipts taxes. He stated that nondiscriminatory taxes could be measured by gross receipts from interstate commerce if properly apportioned but that unapportioned gross receipts taxes were invalid because they "placed on the commerce burdens of such a nature as to be capable, in point of substance, of being imposed ... or added to ... with equal right by every state which the commerce touches, merely because interstate commerce is being done, so that without the protection of the commerce clause it would bear cumulative burdens not imposed on local commerce. . . Id. at 255-256. See Note, State Taxation of Interstate Commerce: The Western Live Stock Case, 52 HaRv. L. REv, 502 (1939) ; Comment, Taxation: Nerw Developments in State Taxation of Gross Receipts from Interstate Commerce, 27 CaLIF. L. REv. 336 (1939); Note, The Multiple Burden Theory in Interstate Commerce Taxation, 40 CoL. L. REv. 653 (1940).

8. 309 U.S. 33 (1940). In upholding the application of the New York City sales tax to certain types of interstate sales, Mr. Justice Stone for the Court said that as "guides to decision" the Court should look "to the purpose of the commerce clause to protect interstate commerce from discriminatory or destructive state action, and at the same time to the purpose of the state taxing power under which interstate commerce admittedly must bear its fair share of state tax burdens, and to the necessity of judicial reconciliation of these competing demands. . "Id. at 49. Referring to earlier cases he said: "Despite mechanical or artificial distinctions sometimes taken between the taxes deemed permissible and those condemned, the decisions appear to be predicated on a practical judgment as to the likelihood of the tax being used to place interstate commerce at a competitive disadvantage." Id. at 45 n.2. See Powell, Neze Light on Gross Receipts Taxes: The Berwind-White Case, 53 Harv. L. Rev. 909 (1940).

9. 322 U.S. 327 (1944). The Court held invalid an application of the Arkansas sales tax to a sale in which the order was solicited by a drummer for acceptance by an extra-state seller who shipped the goods directly to the buyer. In General Trading Co. v. State Tax Comm'n, 322 U.S. 335 (1944), decided the same day, the 
tions and by Freeman v. Hewit ${ }^{10}$ in 1946 the Court was divided five to four in favor of the formal approach. This division of the Court was sufficiently fluid, however, to permit the substantive approach to control decision in an occasional case ${ }^{11}$ and prior to the deaths of Justices Rutledge and Murphy in 1949 the ultimate resolution of the controversy could fairly be said to be in doubt. ${ }^{12}$ Spector Motor Service, Inc. v. O'Connor ${ }^{13}$ in 1951 and Memphis Steam Laundry Cleaner,

Court upheld the application of the Iowa use tax to property acquired through a substantially identical sales transaction. Dissenting in the McLeod case, Justices Douglas, Black and Murphy argued that the result in these cases should "turn on practical considerations and business realities rather than on dialectics." Id. at 335.

10. 329 U.S. 249 (1946). The Indiana gross income tax was held invalid as applied to the receipts from the sale of securities on the New York Stock Exchange by an Indiana resident through an Indiana broker. Justice Frankfurter, writing for the Court, held the tax invalid as a direct tax upon interstate commerce. He rejected the argument that the tax should be upheld because nondiscriminatory: "It is immaterial that local commerce is subjected to a similar encumbrance." Id. at 252. He also said that it was not necessary to show any substantive effect upon the commerce: "An exaction by a State from interstate commerce falls not because of a proven increase in the cost of the product. What makes the tax invalid is the fact that there is interference by a State with the freedom of interstate commerce. . . Trade being a sensitive plant, a direct tax upon it to some extent at least deters trade even if its effect is not precisely calculable." Id. at 256. Justices Black, Douglas and Murphy dissented. Justice Rutledge concurred on the ground that the tax was unapportioned but rejected the reasoning of the majority opinion as returning to the "formalism of another day." Id. at 269. See Powell, More Ado About Gross Receipts Taxes, 60 HARv. L. REv. 501, 710 (1947).

11. In Memphis Natural Gas Co. v. Stone, 335 U.S. 80 (1948), a Mississippi franchise tax was levied upon a pipeline company doing a wholly interstate business. Justices Reed, Douglas, Murphy, Black and Rutledge held the tax valid on the theory that it was really upon the local activities of maintaining and keeping in repair the pipe lines and compressor stations within the state. In Interstate Oil Pipe Line Co. v. Stone, 337 U.S. 662 (1949), a Mississippi privilege tax measured by gross income was upheld as applied to a pipe line company transporting oil from oil fields in Mississippi to railroad loading racks also in Mississippi from where it was all shipped out of state. Justices Rutledge, Black, Douglas, and Murphy voted to uphold the tax for the following reasons: "The tax does not discriminate against interstate commerce in favor of competing intrastate commerce of like character. The nature of the subject of the taxation makes apportionment unnecessary; there is no attempt to tax interstate activity carried on outside Mississippi's borders. No other state can repeat the tax." Id. at 668 . Justices Reed, Vinson, Frankfurter, and Jackson dissented on the ground that a tax for the privilege of engaging in interstate commerce had always been held invalid. They emphasized their conclusion that form and not substance should control decision: "This is not because of the financial burden. Other taxes may equally burden the commerce. It is not because in transportation the same result cannot be obtained by levying a tax for intrastate activities measured by gross receipts appropriately apportioned to the activities in the state. It is because the commerce clause of the Constitution does not leave to the states any power to permit or refuse the carrying on of interstate commerce. It likewise bars a state from taxing the privilege of doing interstate commerce or the doing of interstate commerce, with or without fair apportionment even if not discriminatory." Id. at 680 . Justice Burton cast the deciding vote in favor of the tax on the sole ground that he thought the pipe line company was engaged in intrastate, not interstate, commerce and hence clearly subject to a local privilege tax.

12. Barrett, supra note 6 , at 529 .

13. 340 U.S. 602 (1951). The Court held invalid as applied to a trucking company doing a wholly interstate business a Connecticut franchise tax imposed on every corporation carrying on business within the state for the privilege of doing business within the state and measured by $2 \%$ of net income from business transacted within 
Inc. v. Stone ${ }^{14}$ in 1952, however, appear to be definitive decisions by a substantial majority of the Court in favor of the formal approach.

Why this hasty abandonment in the tax cases of the substantive approach which the Court appears to find so comfortable in the regulation cases? While the Court has never answered this question directly, there are suggestions in recent opinions that the retreat to formalism results from a feeling of judicial incompetence to determine the substantive economic effect of state taxes upon the flow of commerce. In Freeman v. Hewit, for example, Mr. Justice Frankfurter stated:

"The immuities implicit in the Commerce Clause and the potential taxing power of a State can hardly be made to depend, in the world of practical affairs, on the shifting incidence of the varying tax laws of the various States at a particular moment. Courts are not possessed of instruments of determination so delicate as to enable them to weigh the various factors in a complicated economic setting which, as to an isolated application of a State tax, might mitigate the obvious burden generally created by a direct tax on commerce." 15

The majority of the Court argues, in effect, that since the Court is unable to determine in fact whether or not a particular tax as ap-

the state. The Court recognized that the tax did not discriminate between interstate and intrastate commerce. It said that the objection to the tax did not rest on a claim that it placed an unduly heavy burden on interstate commerce in return for protection given by the state. It even said, referring to earlier cases, that had Spector done some intrastate business the tax could then have validly reached the income from both intrastate and interstate business. The decision against the tax was based solely upon the ground that the formal incidence of the tax was the privilege of doing business within the state and hence it came within the rule of prior cases striking down state taxes upon the privilege of carrying on a business exclusively interstate in character. Justices Clark, Black, and Douglas, dissenting, charged that the majority opinion resulted in "cloaking a purely verbal standard with constitutional dignity." Exclusively interstate commerce, they said, "receives adequate protection when state levies are fairly apportioned and nondiscriminatory." $I d$, at 614, 615. See Roesken, The Impact of the Spector Decision, 29 Taxes 523 (1951).

14. 342 U.S. 389 (1952). The Court held invalid a Mississippi privilege tax of $\$ 50$ for each county upon each person soliciting business for a laundry not licensed in the state, as applied to a Tennessee firm which sent trucks into Mississippi to pick up and deliver laundry. The Court said that it was unable to determine from the state court opinion whether the tax rested upon the privilege of soliciting interstate business or upon the more local activities of picking up and delivering laundry on regular routes within the state. On the first alternative the Court found the tax invalid under the rule of the Spector case because "a tax imposed upon the solicitation of interstate business is a tax upon interstate commerce itself" and "stands on no better footing than a tax upon the privilege of doing interstate business." Id. at 392,393 . On the second alternative the tax was held invalid even though imposed upon the privilege of conducting intrastate activities because of its discriminatory character. Laundries licensed within Mississippi paid a privilege tax of only $\$ 8$ per truck. All members of the Court concurred in the opinion of the Court except Mr. Justice Black who dissented without opinion. The mystery in the case is why the Court felt it necessary to discuss the Spector case rule at all in view of the formally discriminatory character of the tax.

15. $I d$. at 256 . 
plied serves as a deterrent to commerce, it can best serve the cause of freedom of trade among the states by outlawing all taxes imposed directly upon interstate commerce or upon the privilege of engaging in it. From a similar skepticism as to the ability of the Court to make economic sense out of its decisions in this field, Mr. Justice Black argues that the whole matter should be left up to Congress with the Court stepping in, if at all, only to invalidate taxes which formally discriminate against interstate commerce. ${ }^{16}$

The purpose of this paper is to demonstrate that there is a middle ground between these two views: that the Court is capable of applying considerations of substance in commerce clause tax cases which would give a useful protection to interstate commerce pending Congressional action. The paper will be divided as follows: (1) a brief sketch of the substantive or economic characteristics of the problem. (2) A discussion in general terms of a proposed judicial approach to solution of the problem. (3) Illustrations of the application of this approach to a number of specific state tax situations. (4) Suggestions for Congressional action to go even further in insuring equality of tax treatment between intrastate and interstate commerce.

\section{The Economic Characteristics of the Problem}

Our federal system of government has resulted in an unbelievably complicated state and local government taxing system. Within the continental limits of the United States forty-eight states and the District of Columbia plus thousands of cities, towns, counties, parishes, and special assessment districts independently assess and collect taxes. In addition to its federal tax obligations, a large interstate business today may easily find itself paying taxes to hundreds of separate taxing jurisdictions.

This taxing structure is marked by its lack of uniformity. True, the bulk of local government revenue comes from ad valorem property taxes, ${ }^{17}$ but even here there is variation. Some jurisdictions have special taxes on intangibles. Many have special forms of property taxation for particular kinds of business. In lieu taxes for public utilities are not uncommon. And the trend in the larger cities is toward a variety of taxes. Among those commonly used are taxes on sales, net income, gross income, licenses and permits, admissions, cigarettes,

16. See his concurring opinion in Northwest Airlines v. Minnesota, 322 U.S. 292, 301 (1944) and his dissenting opinions in McCaroll v. Dixie Greyhound Lines, 309 U.S. 176, 183 (1940); Gwin, White \& Prince v. Henneford, Inc., 305 U.S. 434, 442 (1939); J. D. Adams Mfg. Co. v. Storen, 304 U.S. 307, 316 (1938).

17. About $88 \%$ came from this source in 1951. 19 TAx Polrcy 4 (1952). 
liquor, franchises, automobiles, racing, businesses, hotel rooms, parking meters, and gasoline. ${ }^{18}$

Even more striking is the lack of uniformity in the taxing structures of the states. As is true of the cities, each state relies on a variety of taxes. State lists of 20 or more types of taxes are common, and the principal revenue producers vary from state to state. Massachusetts, New York, and Pennsylvania, for example, rely heavily on net income taxes for their revenue. Massachusetts and New York collect 55\% and $44 \%$, respectively, from their corporation and personal net income taxes and Pennsylvania collects $18 \%$ from its corporate net income tax. ${ }^{19}$ The next largest source of revenue in each of these states is gasoline and motor vehicle taxes, which account for $13 \%, 20 \%$, and $35 \%$, respectively, of total collections. Michigan, West Virginia, and Washington, on the other hand, collect more than half their taxes from sales, use or other gross income taxes with Michigan receiving 55\%, West Virginia 58\%, and Washington 52\%. The next highest source of revenue in these states is again gasoline and motor vehicle taxes which account for $21 \%, 26 \%$, and $29 \%$, respectively. California has a combination of these two systems, collecting over $42 \%$ from sales and use taxes, $27 \%$ from gasoline and motor vehicle taxes, and $18 \%$ from corporate and personal net income taxes. Other variations appear. Nebraska collects over $30 \%$ from a general property tax and $48 \%$ from gasoline and motor vehicle taxes. Nevada gets $19 \%$ from a general property tax, $33 \%$ from gasoline and motor vehicle taxes, and about $15 \%$ from taxes on gambling. Delaware gets $15 \%$ of its total tax collections from franchise taxes imposed on the corporate stock of all Delaware corporations. New Jersey, having neither an income nor a sales tax, collects $46 \%$ of its total revenue from gasoline and motor vehicle taxes. And Texas is able to exploit its unique natural resources by getting about $30 \%$ of its collections from severance taxes on petroleum and natural gas. This lack of uniformity is due in part simply to the accidents of growth of tax legislation in separate jurisdictions having no compulsion toward uniformity. But in considerable measure it is due also to variations inherent in the conditions of the states themselves. For example, a highly industrialized eastern state will be able to obtain its revenues from sources that are not available in the more agrarian southern and western states. Each state has a different mixture of natural resources and industry and must tailor its taxing system accordingly.

18. Tax collections by type of tax for cities of 300,000 and over are given in CCH, TAX Systens 310 (13th ed. 1952).

19. The figures used in this paragraph were derived from the tax charts in $\mathrm{CCH}$, TAX SySTEMS 12-154 (13th ed. 1952). 
Uniformity is also lacking in the size of the tax burden. In 1951, for example, the state tax burden per capita ranged from $\$ 35$ in New Jersey to $\$ 98$ in Louisiana. ${ }^{20}$ Wide variations existed even among adjoining states. Thus Louisiana's per capita burden of $\$ 98$ can be compared with $\$ 46$ in Mississippi and $\$ 46$ in Texas. New Jersey's $\$ 35$ can be compared with $\$ 88$ in Delaware and $\$ 62$ in New York. These variations are partly explained by two factors. Some states traditionally have higher standards of public services which must be paid for by a total tax burden larger than that of states with lower standards in this respect. In other states many of the services may be performed by local rather than state governments with a consequent shifting of more of the burden to the local ad valorem property tax. ${ }^{21}$ Hence a true comparative picture could be obtained only if figures on the total tax burden, state and local, were available. ${ }^{22}$

In view of this complicated taxing structure what can be said regarding the actual economic effect of particular taxes upon the flow of commerce? ${ }^{23}$ Consider first taxes which bear upon the production and distribution of goods. Obviously, it is not possible to insure competitive equality taxwise of similar goods in a single market. ${ }^{24}$ The

20. The figures used in this paragraph are from U.S. Bureau of the Census, State TAx Coltectrons IN 19514 (State Finances; 1951, No. 4).

21. In 1942 in New Jersey, state taxes represented only $28.8 \%$ of the total of state and local tax collections while in Delaware they represented $70 \%$. On the other hand, Mississippi and Texas state tax collections represented $57 \%$ and $48 \%$ respectively while in Louisiana they represented but $67 \%$. Id. at 8 . No comparable data is available for more recent years. Id. at 2 .

22. The Bureau of the Census apparently does not collect these figures. See, however, Freeman, The State and Local Tax Burden, 26 STATE Government 116, 118 (1953) for a study of total state and local tax burdens in terms of percentage of income Dayments to individuals. This study shows a range from a high of $12.04 \%$ of income payments in Louisiana to a low of $6.17 \%$ in Delaware.

23. The author has been unable to discover in economic literature any detailed analysis of the problems considered here. A limited attempt to apply economic theory to an analysis of the Supreme Court decisions can be found in Spahr, The Supreme Court on the Incidence and Effects of Taxation, 10 SMITn College STUDIES IN HISTORY 97 (1925). Similar problems may arise in international situations. See Bloch and Heilemann, International Tax Relations, 55 Y ALE L.J. 1158 (1946).

24. See Lockhart, Gross Receipts Taxes on Interstate Transportation and Communication, 57 HARv. L. REv. 40, 75 (1943): "If, in fact, a heavier burden happens in some cases to fall on interstate than on local commerce, this is merely the accidental incident of interstate commerce being subject to two different taxing jurisdictions. Such inequality is inevitable under our federal system, and is just as likely to work to the advantage of interstate commerce as to its disadvantage. To condemn all taxes affecting interstate commerce because of the possibility of such inequality would be utterly impractical, and would result in condemning much of the current taxation by which interstate commerce pays its fair share of the local tax burden." See also Traynor, State Taxation and the Commerce Clanse in the Supreme Court, 1938 Term, 28 CALIF. L. REv. 168, 173 (1940): "Taxation in one state is not an immunization against taxation in other states. As a result values which shift from state to state may sometimes be more heavily taxed than those which never shift at all, just as they may sometimes be less heavily taxed as a result of the shift than if they had remained in one state. Goods in one state, for example, may bear the burden not only of an excise tax on manufacturing but of an ad valorem 
tax costs incurred in the production of the goods will vary widely, depending on the total tax burden and the tax structure of each of the states involved. Generally speaking goods produced in a state with a high per capita tax burden will be at a disadvantage as compared with those produced in a state with a low tax burden. But if the hightax-burden state derives the major portion of its revenue from property or income taxes, the competitive positions may be reversed. To illustrate this impact of varying taxing structures, ${ }^{25}$ assume that manufacturers from Illinois, Oregon, California and Indiana all sell competitive goods in a particular market. Each manufacturer will have paid local property, license and other similar taxes in varying amounts. With respect to state taxes, the Illinois manufacturer will have paid no major state tax. The Oregon manufacturer will have paid a state tax on net income of $8 \%$ (subject to a partial credit for personal property taxes paid). The California manufacturer will have paid a $4 \%$ net income tax; the Indiana manufacturer a $11 / 4 \%$ gross income tax. ${ }^{26}$

Even though competitive equality can never be achieved, it is possible to make some generalizations regarding the effect which any new tax will have upon the existing competitive picture, whatever it may be. Assume that State $\mathrm{X}$ is in need of additional sources of revenue. What will be the impact upon the flow of interstate commerce if it selects a marketing tax, such as a sales tax? If the tax is imposed at the same rate upon all sales to purchasers within the state regardless of the origin of the goods, there will be no change in the existing competitive position within local markets. If the tax bears more heavily upon goods coming from out of the state, it will improve the competitive position of the local producer as against all others, even though some out-of-state goods still may come into the market with lower tax

tax and a tax on their retail sale, while goods in another state may be free from burdens until the moment of sale or use. It is thus a matter of chance whether out-of-state goods are at an advantage or disadvantage in competition with local goods, and the possibility of the latter situation represents not a discrimination but a risk attendant upon the privilege of receiving government protection in two or more states. Tax burdens will vary from state to state and from product to product; their variability is evidence of the freedom with which states may exercise their taxing power, and it would be a practical impossibility to level them all down to the same plane. A state could not look in all directions at once to determine whence out-ofstate goods came, and what manner and amount of burdens they had incurred along the way, for such a task would involve not only a comparison of burdens on these goods with those on goods of local origin but their comparison in relation to one another, and no state would have the requisite detailed knowledge of the tax systems of every other." See also Powell, New Light on Gross Receipts Taxes: The Berwind-White Case, 53 HaRv. L. Rev. 909, 931 (1940).

25. See Note, Gross Receipts Taxes: A Change in Doctrine, 56 Yale L.J. 898, $905 \mathrm{n} .38$ (1947) where it is suggested that 2353 combinations of taxes are mathematically possible.

26. The figures used in the text were derived from CCH, TAx Systems 12-154 (13th ed. 1952). The fact that these taxes serve as deductions for federal income tax purposes is a leveling influence, however. 
costs than locally produced goods. If interstate sales are exempted from the tax, the competitive position will be altered in favor of goods from out of the state. In short, a marketing tax discriminating against out-of-state goods will probably diminish the flow of commerce into the state; one discriminating in favor of out-of-state goods will probably increase imports; a nondiscriminatory tax paid with respect to all goods should have no effect upon imports. If sales to purchasers outside the state are exempted from the tax, however, it may have the effect, at least in the short run, of stimulating the export of goods from the state.

If State $\mathrm{X}$ decides in favor of a new property tax or manufacturing tax or some other tax which takes effect prior to the marketing stage, other results can be expected. If the tax is nondiscriminatory, it will impair the competitive position of producers from State $\mathrm{X}$ in marketing their products in other states and improve the competitive position of out-of-state producers in State $\mathrm{X}$ markets. If the tax bears more heavily upon producers making interstate sales, it will discourage shipment of goods out-of-state without any compensating advantage to out-of-state producers in State X markets. If such a tax is not so great as to stifle the interstate business of local producers, it will have (to the extent that it is passed on to consumers) the effect of shifting to the out-of-state consumer a larger share of the tax burden of State $\mathrm{X}$ than will be borne by State $\mathrm{X}$ consumers of the same goods.

The competitive position of interstate goods will also be affected adversely whenever more than one state is permitted to tax the same portion of the process of production and distribution. If, for example, both the state in which goods are produced and the state in which they are sold collect taxes upon the retail sale (or use) of the goods, they will bear two marketing taxes where local goods only pay one. If the state of domicile of a corporation doing an interstate business collects a tax upon the corporation's entire net income and the other states in which it does business collect taxes upon allocated portions of the net income, the interstate business will bear a higher income tax load than comparable intrastate businesses. If the state in which goods are produced collects a manufacturing tax measured by the gross receipts from sales of the goods including out-of-state sales and the state of the market collects a sales tax, interstate commerce will be put to a disadvantage to the extent that marketing costs are included in the measure of the manufacturing tax.

Analysis of the effect of taxes which bear upon transportation and communication is somewhat more difficult. ${ }^{27} \mathrm{~A}$ tax which bears

27. See Lockhart, supra note 24. 
more heavily upon interstate transportation or communication than upon comparable intrastate activity will, of course, if reflected in lower intrastate rates, alter the competitive position in local markets in favor of local producers. But under modern conditions and in view of the extensive rate regulation power of such federal agencies as the Interstate Commerce Commission, situations of this kind will seldom if ever arise. The basic problem stems from the fact that any state tax increases the cost of doing business and ultimately will be reflected in the rate structure of the particular concern or industry. The higher the rates charged by any transportation agency, for example, the shorter the distance it is feasible to send goods to market. Hence, any state tax upon transportation and communication agencies can be said to have a deterrent effect upon interstate commerce. Furthermore, the effect of a particular tax is so diffused that a heavy tax burden in one state may affect rates charged throughout a substantial part or even all of the country. The problem here is one of allocation. Each state should be entitled to its fair share of tax revenues from interstate transportation and communication businesses. Any tax which goes beyond that fair share imposes an unnecessary restriction upon the free flow of commerce. The most sensible criterion for determining what is a fair share seems to be that the tax load borne by transportation and communication companies should be roughly equivalent to that borne by business and property generally within any particular state.

\section{A Proposed Judicial Approach to Solution of the Problem}

It appears to the author that the courts can make economic sense out of their decisions in this field within the framework of our federal system by (and perhaps only by) accepting the following two propositions of law as general guides to decision: (1) Any tax which, if applied generally by the states or their subdivisions, would bear more heavily upon interstate commerce than upon like intrastate commerce (i.e., any discriminatory tax) should, absent compelling considerations of local necessity or of judicial expediency, be held invalid. Any tax which would not bear more heavily upon interstate commerce than upon like intrastate commerce should be held valid.

Invalidation of taxes discriminating against interstate commerce makes economic sense in terms of the national interest in freedom of trade. As we have seen, imposition of such taxes by the state of the market upon the importation of goods from without the state distorts the existing competitive picture, whatever it may be, in favor of the 
local producer. Furthermore, to the extent that the tax does bear more heavily upon the out-of-state producer the normal political restraints upon excessive taxes may be weakened since the voice of the local producer seeking protection against competition may speak louder than that of the consumer who must pay the bills. When the state of production places discriminatory taxes upon producers who sell their goods in interstate commerce, the effect is to deter the exportation of goods without giving any corresponding impetus to importation. Again the normal political restraints upon excessive taxation will be weakened since to the extent that goods are exported and the manufacturer does not absorb the tax the out-of-state consumer will be forced to pay a larger share of the tax burden of the producing state than is paid by the intrastate consumer of the same goods. Political considerations may provide even less of a check upon discriminatory taxation of transportation and communication companies because the effect of the tax upon rates is so diffused. And the cumulative effect of the adoption of such taxes by many states would be particularly destructive to the free flow of commerce.

Judicial application of the rule against discrimination presents many difficult problems, not all of which are readily perceived. In the first place, there is the problem of determining which taxes are in fact discriminatory. ${ }^{28}$ Taxes which make a formal discrimination against interstate commerce (e.g., special taxes upon goods from outside the taxing state or taxes imposing a higher rate upon interstate than intrastate commerce) have long been recognized and condemned by the Court. ${ }^{29}$ Apparently even Mr. Justice Black agrees that such taxes should be condemned. ${ }^{30}$ But to be meaningful the rule against discrimination must cut deeper. Many taxes which are formally nondiscriminatory may in fact bear more heavily upon interstate than upon

28. For an excellent discussion of this problem suggesting detailed rules to be used by the courts in determining whether or not a tax discriminates against interstate commerce, see Overton, State Taxation of Interstate Commerce, 19 Tenn. L. REv. 870 (1947).

29. The fountainhead case was Welton v. Missouri, 91 U.S. 275 (1876). Among the later cases are the following: Guy v. Baltimore, 100 U.S. 434 (1880); Webber v. Virginia, 103 U.S. 344 (1881); Walling v. Michigan, 116 U.S. 446 (1886); Nippert v. Richmond, 327 U.S. 416 (1946); Bethlehem Motors Corp. v. Flynt, 256 U.S. 421 (1921) ; Best \& Co. v. Maxwell, 311 U.S. 454 (1941); Memphis Steam Laundry Cleaner, Inc. v. Stone, 342 U.S. 389 (1952). But cf. New York v. Roberts, 171 U.S. 658 (1898) ; Armour \& Co. v. Virginia, 246 U.S. 1 (1918).

30. Dissenting in Gwin, White \& Prince v. Henneford, Inc., 305 U.S. 434, 445 (1939) he referred to "strong logical grounds upon which this Court has based its invalidation of State laws actually imposing unjust, unfair, and discriminatory burdens against interstate commerce as such. . He also signed the opinion of the Court in Best \& Co. v. Maxwell, 311 U.S. $454^{\circ}$ (1941). But cf. his dissent without opinion in Memphis Steam Laundry Cleaner, Inc. v. Stone, 342 U.S. 389 (1952). 
intrastate commerce. ${ }^{31}$ For example, special legislative classifications (such as special taxes on railroads, telegraph companies, pipelines, peddlers or drummers) may result in discriminations against interstate commerce. As Professor Powell observed three decades ago: ${ }^{32}$

"When a statute picks a special subject for a special tax, the object of its desire is practically certain to be forced into a generosity in excess of that indulged in by property and business generally. If this special subject is interstate commerce or includes interstate commerce, enterprise which straddles a state line is paying more than some or all of the enterprise that is of interest only to the taxing state. The danger that the taxing state will heed the monition that charity beginneth at home is sufficient to justify the court in looking askance at any exaction on interstate commerce that is not certain to be matched by equivalent exactions on all local commerce." 33

The Supreme Court has thus far failed to recognize explicitly the commerce clause implications of special classifications. ${ }^{34}$ In earlier years the Court dealt with many special state taxes which were discriminatory in their impact upon interstate commerce. The Court was justly suspicious of these taxes and held many of them invalid. ${ }^{35}$ But

31. Recognition of this fact by the Court has been limited largely to cases involving local taxes on drummers. Nippert v. Richmond, 327 U.S. 416 (1946); Best \& Co. v. Maxwell, 311 U.S. 454 (1941) ; Robbins v. Shelby County Taxing Dist., 120 U.S. 489 (1887); Memphis Steam Laundry Cleaner, Inc. v. Stone, 342 U.S. 389 (1952).

32. Powell, State Income Taxes and the Commerce Clanse, 31 YALE L.J. 799, 801 (1922).

33. See also Spahr, supra note 23 at 142: "But it must be conceded that an outwardly non-discriminatory tax on those dealing in particular kinds of goods is substantially a tax on imports if the articles selected are such as are produced without and not within the taxing area. Such a tax must be borne chiefly by consumers of the imported commodities and is likely to check importation, especially if an untaxed substitute is produced within the taxing state."

34. In 1925 Spahr stated: "The constitutional law of taxation recognizes the significance of formal discrimination, with a few conspicuous exceptions . . . . but gives no attention to the substantial discrimination effected by the discreet selection of taxable articles, although a court may find it possible to afford relief in a particular situation ostensibly upon grounds unrelated to the charge of discrimination." Ibid. The only recent reference to the problem came in the dissenting opinion of Justices Douglas and Rutledge in Joseph v. Carter \& Weekes Steve. Co., 330 U.S. 422, 439 (1947), in which they distinguished an earlier case on the ground that the tax there in question was applicable to transportation companies only and added: "Whatever may be said for the proposition that a gross receipts tax, applicable only to transportation companies, may readily become the instrument for impeding or destroying interstate commerce, that consideration has no relevancy here. For in the present case ... all businesses are taxed alike. . P Political restraints, perhaps lacking when a particular type of business is singled out for special taxation, would not be absent here."

35. E.g., a chronological listing of the significant license, privilege and income tax cases decided by the Court during the period 1873-1900 shows the following: Case of the State Freight Tax, 82 U.S. 232 (1873) (tonnage tax on railroads, canals, steamships, etc., held invalid) ; State Tax on Railway Gross Receipts, 82 U.S. 284 (1873) (gross receipts tax on railroad, canal and transportation companies 
it did so without analysis of the substantive issues involved. ${ }^{36}$ Instead it used a conceptual notion not unfamiliar to the more recent decisions; if the taxes were upon interstate commerce or the privilege of engaging in it, they were held invalid; if their formal incidence was upon intrastate commerce they were usually held valid. This judicial failure to make the discriminatory features of special taxes an explicit basis of decision had two unfortunate results: (1) Special taxes falling formally upon intrastate commerce but with discriminatory effects as serious as those involved in similar taxes falling formally upon interstate commerce were upheld. Thus special license taxes upon peddlers were upheld on the ground that they were engaged in intrastate commerce even though the goods sold by them came predominantly from outside the state, while special license taxes upon drummers were banned because they were engaged in interstate commerce. ${ }^{37}$ (2) By the mid-1920's the general statements in the earlier cases that any taxes imposed upon interstate commerce itself were invalid were used as a basis for holding invalid the application to interstate commerce of new types of nondiscriminatory taxes of general applicability. ${ }^{38}$

held valid); Osborne v. Mobile, 83 U.S. 479 (1873) (flat sum license tax on railroad and express companies held valid); The Delaware Railroad Tax, 85 U.S. 206 (1874) (net income tax on railroad and canal companies held valid); Welton v. Missouri, 91 U.S. 275 (1876) (discriminatory peddler tax held invalid); Machine Co. v. Gage, 100 U.S. 676 (1880) (flat sum tax on peddlers of sewing machines held valid) ; Telegraph Co. v. Texas, 105 U.S. 460 (1881) (excise tax on telegraph messages held invalid as to interstate messages); Wiggins Ferry Co. v. East St. Louis, 107 U.S. 365 (1883) (flat sum license fee on keepers of ferries held valid) ; Pickard v. Pullman Southern Car Co., 117 U.S. 34 (1886) (flat sum privilege tax on operation of Pullman cars held invalid) ; Robbins v. Shelby County Taxing Dist., 120 U.S. 489 (1887) (license tax on drummers held invalid); Fargo v. Michigan, 121 U.S. 230 (1887) (gross receipts tax on railroads held invalid); Philadelphia \& Southern S. Co. v. Pennsylvania, 122 U.S. 326 (1887) (gross receipts tax on transportation and railroad companies held invalid); Leloup v. Port of Mobile, 127 U.S. 640 (1888) (flat sum license fee on telegraph companies held invalid); Crutcher v. Kentucky, 141 U.S. 47 (1891) (license fee on express business held invalid); Maine v. Grand Trunk Ry., 142 U.S. 217 (1891) (gross receipts tax on railroads held valid); Brennan v. Titusville, 153 U.S. 289 (1894) (license fee on drummers held invalid); Postal Tele. Cable Co. v. Charleston, 153 U.S. 692 (1894) (flat sum license fee on the intrastate business of telegraph companies held valid); Emert v. Missouri, 156 U.S. 296 (1895) (license tax on peddlers held valid); Adams Express Co. v. Ohio State Auditor, 165 U.S. 194 (1897) (property tax computed for express companies on an allocated portion of total value of capital stock held valid).

36. In Philadelphia \& Southern S. Co. v. Pennsylvania, 122 U.S. 326, 344 (1887), the Court referred to the fact that the tax there was "not a general tax on the incomes of all the inhabitants of the state; but a special tax on transportation companies" but only for the purpose of showing that the tax was not a tax on income but rather a tax on transportation.

37. E.g., compare Caskey Baking Co. v. Virginia, 313 U.S. 117 (1941) (peddler tax) with Nippert v. Richmond, 327 U.S. 416 (1946) (drummer tax). See also the recent approval of this distinction in Memphis Steam Laundry Cleaner, Inc. v. Stone, 342 U.S. 389 (1952).

38. Ozark Pipe Line Corp. v. Monier, 266 U.S. 555 (1925) (general corporate franchise tax measured by a percentage of allocated capital stock held invalid); Alpha Portland Cement Co. v. Massachusetts, 268 U.S. 203 (1925) (general corporate franchise tax measured by allocated net income held invalid). 
Thus a rule fashioned in the context of special state taxes, upon railroads, express companies, telegraph companies, and similar interstate enterprises came to be used to forbid the application to interstate businesses of general state taxes measured by net or gross income.

Judicial recognition of the fact that special tax classifications may involve practical discrimination against interstate commerce is essential if commerce clause cases are to be decided in terms of substance rather than form. Recognition of the problem does not mean, however, that all special classifications embodying interstate commerce must be held invalid.

Legitimate reasons of policy or of administrative expediency are ample justification for many types of classifications even though they may also have some impact upon interstate commerce. Even when the legislative motive may be to discriminate against interstate commerce the understandable judicial reluctance to examine legislative motive will usually forbid its consideration. ${ }^{39}$ In applying the equal protection clause the Court has long recognized that undue judicial interference with legislative discretion in classifying for tax purposes would be intolerable:

"As we have repeatedly held, the equal protection clause of the Fourteenth Amendment does not prevent a State from classifying businesses for taxation or impose any iron rule of equality. Some occupations may be taxed though others are not. Some may be taxed at one rate, others at a different rate. Classification is not discrimination. It is enough that those in the same class are treated with equality." 40

"That the states may classify property for taxation; may set up different modes of assessment, valuation and collection; may tax some kinds of property at higher rates than others; and in making all these differentiations may treat railroads and other utilities with that separateness which their distinctive characteristics and functions in society make appropriate-these are among the commonplaces of taxation and of constitutional law." 41

Clearly, the commerce clause should not be used to nullify this wise policy; yet such nullification would be the practical result of a

39. Cf. Ohio Tax Cases, 232 U.S. 576, 593 (1914): "The present act does not on its face manifest a purpose to interfere with interstate commerce, and we are unable to accept the historical facts alluded to as sufficient evidence of a sinister purpose, such as would justify this court in striking down the law. We could not do this without in effect denouncing the legislature of the State as guilty of a conscious attempt to evade the obligations of the Federal Constitution." But cf. Dykstra, Legislative Favoritism Before the Courts, 27 IND. L.J. 38 (1951).

40. Caskey Baking Co. v. Virginia, 313 U.S. 117, 121 (1941).

41. Nashville, C. \& St. L. Ry. v. Browning, 310 U.S. 362, 368 (1940). 
rule that interstate commerce business cannot be subjected to any taxes other than those of the widest general applicability.

Here, then, is an exceedingly difficult problem, but one of a kind familiar to the courts in the application of the commerce clause in regulation cases. In essence what the court must determine in each case is whether the risk that interstate commerce will be subjected to a discriminatory burden is outweighed by the local interest in freedom to classify for tax purposes. The policy of the commerce clause would justify invalidating narrow classifications embodying predominantly interstate commerce business; the local interest in freedom of classification would justify upholding broader classifications which include predominantly local business. Political restraints upon excessive taxation would, of course, be weak in the former case, strong in the latter. Thus the courts might well condemn special taxes on railroads (in states where their business is predominantly interstate) and yet uphold special taxes on broader classes such as corporations or manufacturing. Difficult borderline cases exist here as in other areas of application of the commerce clause, but at least considerations of substance can be applied in arriving at their solution.

Failure of the state to apportion properly a particular tax to activities or property within the state may also involve problems of discrimination. While apportionment has been largely a due process concept, it also has commerce clause implications. An unapportioned tax is in effect discriminatory as to subject though not as to rate. ${ }^{42}$ A local business is taxed only upon property, activities or income located or arising within the boundaries of the state. To apply the same tax without apportionment to the interstate enterprise is to tax it upon a broader subject-property activities and income located or arising outside as well as inside the state. While this form of discrimination does not involve the same type of danger as special classification (i.e., the normal political restraints upon an excessive rate of taxation are present) it does involve the equally substantial danger that the same property, activities or income may be subjected to taxation by more than one state. Local business bears only one state tax upon its entire business or property, but if the states are permitted to reach beyond their boundaries for taxable subjects interstate business may pay several state taxes upon its entire business. States may be reckoned as self-contained units free to frame their own taxing systems without heeding systems elsewhere if, and only if, the collector's greedy hand is stopped at the borders.

42. Mr. Justice Black apparently contends that unapportioned taxes do not involve discrimination against interstate commerce. See his dissent in Gwin, White \& Prince v. Henneford, Inc., 305 U.S. 434, 442 (1939). 
The Supreme Court has long recognized this problem and required apportionment in most state taxing situations. In the earlier cases the rationale was essentially due process, although commerce clause language was also used. ${ }^{43}$ More recently the requirement of apportionment has been justified in terms of the "multiple burden" approach: An unapportioned tax, though nominally local, "in its practical operation discriminates against interstate commerce, since it imposes upon it, merely because interstate commerce is being done, the risk of a multiple burden to which local commerce is not exposed." 44 In one area the Court apparently has found that local policy is strong enough to outweigh the national policy in favor of apportionment. Although there are no recent cases in which the matter has been discussed, it appears settled that net income taxes and franchise taxes measured by net income, property or capital stock may be applied to individuals domiciled within the state and to domestic corporations without apportionment, even though such taxes may frequently impose substantial burdens on interstate commerce. ${ }^{45}$ Further judicial examination of the decisions in this area appears unlikely and for the moment unnecessary, however, since most states seem to have found that the local interest is best served by not discouraging the interstate operations of domiciliaries and voluntarily provide for apportionment. One other problem arises from the fact that some taxes, such as sales and license taxes, ${ }^{45 a}$ do not readily lend themselves to apportionment.

At best, however, courts can do only a partial job in the apportionment field. ${ }^{46}$ Obviously, they are not competent to formulate and impose upon all states uniform apportionment formulas. As each individual apportionment formula comes before it, the Court can do no

43. The cases are discussed in Barrett, supra note 6 , at 497 et seq.

44. Gwin, White \& Prince v. Henneford, Inc., 305 U.S. 434, 439 (1939). See also Western Live Stock v. Bureau of Revenue, 303 U.S. 250 (1938) ; and Adams Mfg. Co. v. Storen, 304 U.S. 307 (1938).

45. The net income tax cases are cited and discussed in Altaran \& Keesling, Allocation of Income in State Taxation 30 (2d ed. 1950). See also Rock Island Refining Co. v. Oklahoma Tax Comm., 322 U.S. 711 (1944) (per curiam opinion). For cases upholding franchise taxes on domestic corporations doing interstate business in several states measured by the entire capital stock, see Kansas City, M. \& B. R.R. v. Stiles, 242 U.S. 111 (1916) ; Kansas City, Ft. S. \& M. Ry. v. Botkin, 240 U.S. 227 (1916) ; Cream of Wheat Co. v. County of Grand Forks, 253 U.S. 325 (1920); and cf. Newark Fire Ins. Co. v. State Board of Tax Appeals, 307 U.S. 313 (1939).

For a suggestion that the present Court may be reluctant to uphold the right of domiciliary states to tax without apportionment, see Standard Oil Co. v. Peck, 342 U.S. 382 (1952), denying the state of domicile the right to impose a property $\operatorname{tax}$ on the entire value of a fleet of river boats and barges.

45a. The special problems concerning these taxes will be dealt with at length later in this paper.

46. Altman \& Keesling, op. cit. supra note 45. Silverstein, Problems of $A p$ portionment in Taxation of Multistate Business, 4 TAX L. REV. 207 (1949). 
more than recognize that "by its very nature the problem is incapable of precise and arithmetical solution" and uphold the local formula unless it can be shown "to project the taxing power of the state plainly beyond its borders." 47 Frequently, this action may result in subjecting the interstate enterprise to some degree of multiple taxation since the amounts allocated to the various states involved can easily exceed $100 \%$. A complete solution of the apportionment problem can come only as a result of Congressional action. Suggestions for such action will be discussed in the concluding section of this paper.

Application of the second proposition, that nondiscriminatory state taxes should be upheld whatever their relationship to interstate commerce, would run counter to the trend of recent decisions of the Supreme Court. But to the author no valid reason of substance appears why any state tax of wide general application, nondiscriminatory in rate and fairly apportioned to activities within the state, should not be sustained whatever its formal incidence. Take the Spector Motor case as an example. The Court holds there that a corporate franchise tax, applicable to all corporations doing business within the state, on the privilege of doing such business measured by net income properly apportioned to income from activities within the state cannot be applied to a wholly interstate business. Yet it says that such a tax can apply to the net income from all business done within the state, including interstate business, earned by any concern which does some intrastate business, however small and unprofitable it may be. Is there any justification of substance for such a distinction? Why should a tax be held invalid if placed "directly" upon interstate commerce and yet upheld if its formal incidence is some local incident of the commerce? Why should a tax upon the sale of the goods be forbidden when the goods are ordered across state lines prior to shipment when a similar tax with the same economic effects upon the flow of commerce is sustained if the goods enter the state before the sale is made, or if the tax is imposed upon the storage or use of the goods immediately after they enter the state?

What are the justifications that the Court gives for these distinctions? First, there is the appeal to precedent. "The cases abound in statements to the effect that the privilege of carrying on interstate commerce itself is immune from state taxation." 48 "[T] his Court has never interpreted the commerce clause to allow a state tax for the priv-

47. Nashville, C. \& St. L. Ry. v. Browning, 310 U.S. 362, 365 (1940). See also International Harvester Co. v. Evatt, 329 U.S. 416, 422 (1947).

48. Interstate Oil Pipe Line Co. v. Stone, 337 U.S. 662, 677 (1948) (Mr. Justice Reed's dissent). 
ilege of carrying on interstate commerce or one upon that commerce itself." "49 The short answer to this argument may well be that there is no valid reason for permitting the confusions of the past to control the future. A longer answer, which cannot be spelled out in detail here, would suggest that the precedents are not nearly so clear as the Court suggests when re-examined in terms of what was actually decided as opposed to what was said. Prior to 1918 the only important nondiscriminatory tax of general applicability that the Supreme Court was asked to rule upon was the ad valorem property tax and the Court went to great lengths to sustain its application. Not only was the physical property of concerns engaged in interstate commerce subjected to this tax, but the states were also permitted to get at a fair proportion of the intangible unitary value of interstate transportation and communication companies. ${ }^{50}$ Beginning in 1918 the Court decided several cases involving apportioned general taxes on (or measured by) net income in which the taxes were upheld even though applied to net income derived from interstate commerce activities. ${ }^{51}$ A few corporate franchise taxes, properly apportioned, were also upheld. ${ }^{52}$ But most of the taxes which came before the Court were either special taxes ${ }^{63}$ (such as taxes on railroads, express companies or telegraph companies) or taxes which sought to impose clearly discriminatory burdens on foreign corporations under the guise of the privilege to exclude. $^{54}$ While the Court rarely alluded to the special problems of discrimination involved in special taxes and instead talked in terms of forbidding taxes upon interstate commerce or the privilege of engaging in it, the actual decisions were consistent with the affirmative rule stated herein. In his monumental review of the cases in Harvard Laze Review in 1919 Professor Thomas Reed Powell concluded that there was no precedent against application of a general net income tax even to a company doing a wholly interstate business. ${ }^{55} \mathrm{He}$ argued that a

49. $I d$. at 680 .

50. The cases are discussed in Powell, Indirect Encroachment on Federal Authority by the Taxing Powers of the States. $V$., 32 HARv. L. REv. 234 (1919).

51. U.S. Glue Co. v. Oak Creek, 247 U.S. 321 (1918) ; Shaffer v. Carter, 252 U.S. 37 (1920); Underwood Typewriter Co. v. Chamberlain, 254 U.S. 113 (1920); Atlantic Coast Line R.R. v. Daughton, 262 U.S. 413 (1923); Matson Navigation Co. v. State Board of Equalization, 297 U.S. 441 (1936).

52. E.g., St. Louis S.W. Ry. v. Arkansas, 235 U.S. 350 (1914).

53. E.g., cases cited stopra note 35 .

54. E.g., Western Union Tel. Co. v. Kansas, 216 U.S. 1 (1910); Looney v. Crane Co., 245 U.S. 178 (1917); International Paper Co. v. Mass., 246 U.S. 135 (1918). This whole line of cases is discussed in Powell, Indirect Enrocachment on Federal Authority by the Taxing Powers of the States. II., 31 HARv. L. REv. 572 (1918).

55. Powell, Indirect Encroachment on Federal Authority by the Taxing Powers of the States. VII., 32 HaRv. L. REv. 634, 639 (1919). 
similar rule might not be entirely foreclosed if a general gross receipts tax should come before the Court (an event he thought unlikely). And he thought that such general taxes might be sustainable, even though imposed upon the privilege of doing business, on the theory that in substance they were the same as taxes on income itself. ${ }^{56}$ As late as 1921, Professor Powell was able to generalize: "All the cases which have declared that the States cannot tax interstate commerce will be found to be cases involving special rather than general taxes. Whenever it has been certain that interstate commerce could not in some way be discriminated against, the tax has been sustained." ${ }^{57}$ In 1925 the Court held invalid two allocated state franchise taxes upon foreign corporations on the ground that any excise tax on a company doing exclusively interstate business "burdens interstate commerce and is therefore invalid without regard to measure or amount." 58 It was not until the Puget Sound Stevedoring ${ }^{59}$ case in 1937 that the Court held invalid a tax of wide general applicability properly apportioned to activities within the state (a tax for the privilege of engaging in business activities within the state measured by gross receipts). Clearly, then, precedent alone (at least aged precedent) is not enough to compel the Court to go on invalidating states taxes upon formal grounds which have no relation to substance.

Second, there is the argument based on principle. This argument appears to run somewhat along the following lines. (1) The commerce clause "by its own force created an area of trade free from interference by the States." ${ }^{0}$ Time and again it has been said that the purpose of the commerce clause was to create an area of free trade among the states. ${ }^{61}$ (2) This free trade notion goes further than merely restraining the states from imposing duties or imposts on imports and exports-more than state protective tariffs is outlawed. Nondiscriminatory state taxes may also be banned.

"Of course a State is not required to give active advantage to interstate trade. But it cannot aim to control that trade even

56. Id. at 640 .

57. Powell, Taxation of Things in Transit. IV., 7 VA. L. Rev. 497, 531 (1921).

58. Alpha Portland Cement Co. v. Mass., 268 U.S. 203, 217 (1925) ; Ozark Pipe Line Co. v. Monier, 266 U.S. 555 (1925).

59. Puget Sound Stevedoring Co. v. Tax Comm'n, 302 U.S. 90 (1937); cf. Fisher's Blend Station, Inc. v. Tax Comm'n, 297 U.S. 650 (1936) (same tax held invalid as applied to unapportioned gross receipts of radio station).

60. Freeman v. Hewit, 329 U.S. 249, 252 (1946).

61. See Mr. Chief Justice Hughes' dissent in McGoldrick v. Berwind-White Coal Min. Co., 309 U.S. 33, 61 (1940); McLeod v. J. E. Dilworth Co., 322 U.S. 327,330 (1944) ("The very purpose of the Commerce Clause was to create an area of free trade among the several States.") ; Joseph v. Carter \& Weekes Steve. Co., 330 U.S. 422, 428 (1947); Mr. Justice Reed's dissent in Interstate Oil Pipe Line Co. v. Stone, 337 U.S. 662, 682 (1949). 
though it desires to control its own. It cannot justify what amounts to a levy upon the very process of commerce across States lines by pointing to a similar hobble on its local trade. It is true that the existence of a tax on its local commerce detracts from the deterrent effect of a tax on interstate commerce to the extent that it removes the temptation to sell the goods locally. But the fact of such a tax, in any event, puts impediments upon the currents of commerce across the State line, while the aim of the Commerce Clause was precisely to prevent States from exacting toll from those engaged in national commerce." ${ }^{62}$

(3) But on the other hand this free trade idea does not exclude all state taxation which impinges on interstate commerce. By selecting the right kinds of taxes the states may make interstate commerce pay its way. ${ }^{63}$ The distinction between the permissible and the impermissible in the field of state taxation is not, however, based upon considerations of substance. A tax may be invalid though it is nondiscriminatory, is fairly apportioned, and does not place an unduly heavy burden on commerce. "Even though the financial burden on interstate commerce might be the same, the question whether a state may validly make interstate commerce pay its way depends first of all upon the constitutional channel through which it attempts to do so." 04 Two justifications are given for banning certain nondiscriminatory state taxes. Taxes imposed upon the privilege of engaging in interstate commerce are invalid because the commerce clause delegated to the national government "the exclusive power to tax the privilege to engage in interstate commerce." 65 Since the commerce clause takes away from the states the power to permit or refuse the carrying on of interstate commerce they cannot impose a tax for a privilege which they did not grant. Taxes directly upon interstate commerce are invalid because they interfere with the freedom of interstate com-

62. Freeman v. Hewit, 329 U.S. 249, 254 (1946); see also Joseph v. Carter \& Weekes Steve. Co., 330 U.S. 422, 433 (1947); Spector Motor Service, Inc. v. O'Connor, 340 U.S. 602,607 (1951).

63. In Freeman v. Hewit, 329 U.S. 249, 254 (1946) "in an effort to show that the reach of the Commerce Clause did not destroy the state's power to make commerce pay its way" the Court "elaborated the fact that taxes on the commerce itself was not the sole source of state revenue from that commerce." Quotation from Joseph v. Carter \& Weekes Steve. Co., 330 U.S. 422, 429 (1947).

64. Spector Motor Service, Inc. v. O'Connor, 340 U.S. 602, 608 (1951).

65. Ibid. What the Court actually said must have caused Chief Justice Marshall to spin in his grave: "Taxing power is inherent in sovereign states, yet the states of the United States have divided their taxing power between the Federal Government and themselves. They delegated to the United States the exclusive power to tax the privilege to engage in interstate commerce when they gave Congress the power "To regulate Commerce with foreign Nations, and among the several States. . ." Ibid. Yet the Court concluded its opinion with a reference to McCulloch v. Maryland, 4 Wheat. 316 (U.S. 1819), in which Marshall made his strongest argument that the powers of the federal government came not from the states but from the people. 
merce. ${ }^{66}$ In some unexplained manner they constitute a special burden. "Trade being a sensitive plant, a direct tax upon it to some extent at least deters trade even if its effect is not precisely calculable." 67

Several observations can be made regarding these lines of argument. In the first place, the idea of commerce flowing freely back and forth across the map of the United States is an attractive one. This flow would be the greatest, of course, if such commerce were entirely freed from state taxation, but a premium upon interstate shipment of goods to market could result in as uneconomical a system of distribution of goods as could a penalty. Hence, even the advocates of this theory agree that interstate commerce should be required to contribute its fair share to the cost of state and local government. Conceding this proposition, why should there be any limitation except one forbidding discriminatory state taxation? Is there any substantive content to the notion that a tax which bears directly upon interstate commerce is more restrictive of that commerce than one which bears only indirectly? Can it be said, for example, that a sales tax has a greater deterrent effect upon interstate sales than a use tax? True, trade is a sensitive plant and a direct tax upon it, to some extent at least, deters trade. But the same is true of a tax imposed anywhere in the productive process which adds to the costs of carrying on the trade, whether its incidence be termed "direct" or "indirect." Two other suggestions have been made to give substance to this argument. In Freeman v. Hewit, Justice Frankfurter said: "It is immaterial that local commerce is subjected to a similar encumbrance. It may commend itself to a State to encourage a pastoral instead of an industrial society." 68 But this is another problem. Take for example a state tax of 25 cents per pound on all oleomargarine sold within the state. This is not a general tax for revenue, it is a special tax for regulatory purposes and should be so treated by the Court. ${ }^{69}$ The determination of its validity would depend on the kind of balancing of state policy against national interest which is involved in all state regulation cases. The second suggestion was made by Justice Reed in Joseph $v$. Carter \& Weekes Steve. Co., in which he said that the rule used there to invalidate a general gross receipts tax as applied to stevedoring "has reason to support it in the likelihood that such legislation will flourish more luxuriantly where the most revenue will come from foreign or inter-

66. Freeman v. Hewit, 329 U.S. 249, 256 (1946) ; Joseph v. Carter \& Weekes Steve. Co., 330 U.S. 422, 433 (1947).

67. Freeman v. Hewit, 329 U.S. 249, 257 (1946).

68. Id. at 252 .

69. But. cf. A. Magnano Co. v. Hamilton, 292 U.S. 40 (1934). 
state commerce. Thus in port cities and transportation or handling centers, without discrimination against out-of-state as compared with local business, larger proportions of necessary revenue could be obtained from the flow of commerce." 70 The answer to this argument, of course, is that port cities and transportation centers through which large quantities of commerce flow must pay the costs of increased governmental services. If the tax take from interstate commerce cannot be proportioned roughly to the amount of that commerce, such areas will be forced either to reduce the level of governmental services or to call upon local commerce to subsidize interstate commerce.

The Court has remarked that "revenue serves as well no matter what its course" and hence the states can secure interstate commerce contributions to the cost of government from the types of taxes hitherto held permissible. ${ }^{71}$ This argument, however, disregards the many collateral consequences of a shift from one source of revenue to another. A state, for example, may seek to supplement property taxation by net income or gross receipts taxes in order that firms doing a large volume of business with comparatively little real or tangible personal property may contribute their fair share to the cost of government. If the state is told that wholly interstate enterprises must be exempted from these income taxes it must either increase the rate of the property tax or of some other tax which bears in a different way upon business. Many taxpayers would say that the fairest type of state tax is probably that based on net income. Yet if the Spector Motor case means that concerns doing a wholly interstate business are exempt from such a tax, its use may be made difficult if not impossible in many states. Furthermore, a premium is put upon establishing an artificial type of business structure so as to avoid doing any local business in as many states as possible.

Nor are the arguments against the imposition of a privilege tax upon the doing of interstate commerce any more compelling. True, the states cannot prevent the doing of an interstate business. Hence they cannot enforce a privilege tax, or any other kind of a tax, by excluding the taxpayer from the doing of interstate business until the tax is paid. True, also, a tax upon only the privilege of engaging in interstate business would be invalid. But is there any reason why the application of a general tax upon every corporation carrying on business in the state for the privilege of doing such business should, when applied to a corporation doing only interstate business, be termed (as the Court did in Spector Motor) a tax on the privilege of doing inter-

70. 330 U.S. 442,433 (1947).

71. Freeman v. Hewit, 329 U.S. 249, 253 (1946). 
state business? If the conceptual notion that since the state does not grant the privilege to do intertsate business it may not tax it proves too strong for the courts to overcome, why not then look to the substance of the matter and say that the tax will be treated as though it were upon net income or gross receipts or whatever the measure, and disregard the formal incidence, which does not in any event affect the impact of the tax upon commerce? ${ }^{72}$

$$
\text { * * * }
$$

In the cases dealing with the power of Congress to regulate interstate commerce the Court has abandoned in recent years formal distinctions between "direct" and "indirect" effects upon commerce for a test which looks to the economic effect upon commerce of the activities to be regulated. ${ }^{73}$ Judgment as to "practical impeding effects" upon interstate commerce has been substituted "for rubrics concerning its boundaries." 74 Hence it is unnecessary "to search for some sharp point or line where interstate commerce ends and intrastate commerce begins;" 75 the flow of commerce in sugar, for example, may be affected by disrupting the planting of sugar beet seeds as well as by directly burdening the interstate shipment of the sugar.

In the field of state taxation, however, the Court has continued to apply the old formal distinctions. Taxes imposed upon intrastate commerce are upheld regardless of their impact upon the flow of interstate commerce unless they involve a formal and obvious discrimination against that commerce. Taxes imposed directly upon interstate commerce may be held invalid even though they are nondiscriminatory and do not constitute in substance a deterrent to that commerce. And even more subtle distinctions are sometimes drawn when taxes upon business engaged wholly in interstate commerce activity are upheld on the theory that their formal incidence is upon a mere "local incident" of the interstate commerce. ${ }^{76}$

Acceptance of the propositions suggested above as a general guide to decision would largely free the Court from these formal distinc-

72. Professor Powell so argued in 1919 and made then the all too optimistic prediction that the Court would come to treat general franchise and privilege taxes measured by net income in the same fashion as taxes "on" net income and hence sustain them even where solely interstate business is involved. Powell, Indirect Encroachment on Federal Authority by the Taxing Power of the States. VII., 32 HARV. L. REv. 634, 648 (1919).

73. The cases are reviewed in Mandeville Island Farms, Inc. v. American Crystal Sugar Co., 334 U.S. 219 (1948).

74. Id. at 233 .

75. Id. at 232 .

76. E.g., Memphis Natural Gas Co. v. Stone, 335 U.S. 80 (1948). See also the excellent discussion in Martin Ship Service Co. v. Los Angeles, 34 Cal.2d 793. 215 P.2d 24 (1950). 
tions. In broad terms the question in each case (whether interstate or intrastate commerce is the formal subject of the tax) would be does the tax have in substance an adverse effect upon interstate commerce which is not outweighed by some legitimate local interest. On the one hand, any disadvantage that may accrue to interstate commerce from general nondiscriminatory state taxation is far outweighed by the necessity that state and local governments be able to receive revenue from all business activities within their borders to pay for governmental services rendered. On the other hand, formally discriminatory or unapportioned state taxes impose obvious burdens on interstate commerce which seldom can be justified in terms of local need. In intermediate areas the problem is, of course, more difficult, but in most fields of taxation the decisions can be based upon substantive considerations rather than formal distinctions.

\section{Application of the Proposed Solution}

No elaboration of general principles can be held satisfactory until it has withstood the test of application to specific cases. In this section of the paper an attempt will be made to suggest with reference to a few of the principal forms of state taxation what impact the principles advocated in the preceding section would have upon the course of decision.

\section{A. Ad Valorem Property Taxes}

Instrumentalities of Commerce. Ad valorem property taxes today account for approximately one-half of the total of state and local tax collections. ${ }^{77}$ At the time of the early cases dealing with state taxation of interstate commerce, these taxes were the only significant taxes of general applicability, and produced the great bulk of state and local revenue. ${ }^{78}$ All property within a state was subject to such taxation, and it would have been unthinkable to exempt property merely because it was used in an interstate business. Hence the Court has consistently recognized that a state has "the unquestioned right to place a property tax on the instrumentalities engaged in . . . commerce." 79 Such

77. About $88 \%$ of local tax collections in 1951 came from this source. Supra note 17.

78. In 1902, 82\% of state and local revenues came from the property tax. Jensen, Property Taxation in the United States 2 (1931). In 1931 Jensen stated: "From a fiscal point of view property taxes are now and always have been more important than any other tax, and for state and local purposes in the United States, more important than all other taxes together." Id. at 1.

79. Cleveland C.C. \& St. L. Ry. v. Backus, 154 U.S. 439, 445 (1894). The early cases are discussed in Powell, Taxation of Things in Transit. II, 7 VA. L. REV. 245, 246 (1921). 
taxes have been held to affect interstate commerce "only incidentally," and have been thought to be "not inconsistent with the constitutional immunity from the imposition of direct burdens." 80

Apportionment problems have arisen from the migratory habits of such items as railroad rolling stock and ships. ${ }^{81}$ Over the years, through a joint application of due process and commerce clause principles, fairly satisfactory solutions have been reached. Ships which cruise the high seas are taxable at the domicile of their owner unless they achieve fixed situs on waters within another state. ${ }^{82}$ Freight cars and barges which range from state to state are taxed by any formula which operates to allocate a reasonable fraction of the total number to the taxing state. ${ }^{83}$ Airplanes have proved more difficult; in the one case which came before it the Court held that the state of home port could tax total value without clearly indicating the rights of the other states over which the planes operated. ${ }^{84}$ Aside from the airplane problem, the general statement of commerce clause principles made by the Court in Nashville, Chattanooga \& St. Louis Ry. v. Brozening ${ }^{85}$ represents as satisfactory a solution of the problem as is possible through judicial decision alone:

"The guiding principles for adjustment of the state's right to secure its revenues and the nation's duty to protect interstate transportation are by this time well settled. The problem to be solved is what portion of an interstate organism may appropriately be attributed to each of the various states in which it functions. Basic to the accomodation of these conflicting state and national interests is a realization that by its very nature the problem is incapable of precise and arithmetical solution."

The property tax has also given rise to classification problems when the states have sought to go beyond valuation of tangible prop-

80. Virginia v. Imperial Coal Sales Co., 293 U.S. 15, 19 (1934).

81. The early cases are reviewed in Powell, Taxation of Things in Trastsit, 7 VA. L. REv. 167, 245, and 497 (1920-21).

82. The cases are reviewed in Southern Pacific Co. v. Kentucky, 222 U.S. 63 (1911). See also Powell, Taxation of Things in Transit, 7 VA. L. REv. 167, 245, and 497 (1920-21). And cf. Standard Oil Co. v. Peck, 342 U.S. 382 (1952).

83. Ott v. Mississippi Valley Barge Line Co., 336 U.S. 169 (1949); American Refrigerator Transit Co. v. Hall, 174 U.S. 70 (1899); Pullman's Palace Car Co. v. Pennsylvania, 141 U.S. 18 (1891). Cf. Johnson Oil Refining Co. v. Oklahoma, 290 U.S. 158 (1933) (no apportionment) ; Union Tank Line Co. v. Wright, 249 U.S. 275 (1919) (arbitrary apportionment formula). In the most recent case the Court held that the state of domicile of the owner of river boats could not tax the entire value when the boats were operated largely in other states. Standard Oil Co. v. Peck, 342 U.S. 382 (1952).

84. Northwest Airlines, Inc. v. Minnesota, 322 U.S. 292 (1944) ; cf. Standard Oil Co. v. Peck, 342 U.S. 382 (1952) ; Arditto, State and Local Taxation of Scheduled Local Airlines, 16 J. AIR L. \& Com. 162 (1949).

85. 310 U.S. 362,365 (1940). 
erty located within or allocated to the state to apply the property tax to the system or unit value of interstate transportation and communication companies. Special statutes have provided for the assessment of railroad, telegraph and express company property by formulas such as that proportion of capital stock as miles of line (or property) in the state bear to total miles of line (or total property). ${ }^{86}$ These statutes have resulted in the application of the regular property tax rates to values greatly in excess of the actual value of the physical property in the state. In the Adams Express ${ }^{87}$ case, for example, property valued by the company at some $\$ 23,000$ was assessed for tax purposes at almost $\$ 500,000$. In effect, what has been done is to impose the property tax upon the intangible as well as the tangible property of the companies. Yet businesses generally have been subjected to property taxes only upon the actual value of their tangible property. While there has been no discrimination between interstate and intrastate transportation and communication companies, there has been the obvious discrimination between such companies, doing largely interstate business, and other forms of business. ${ }^{88}$ The Court has never faced squarely this problem of discrimination. ${ }^{89}$

Classification problems have arisen also in a series of cases upholding a Minnesota taxing statute which imposes upon certain transportation and communication companies a tax measured by gross receipts in lieu of all other taxes. ${ }^{90}$ This tax has been sustained as being, in effect, no more than "what would be legitimate as an ordinary tax on the property, taken at its real or full value." 01 But no close examination has been made to see that this tax did not in fact result in placing a higher tax burden on these predominantly interstate concerns (in the Cudahy ${ }^{92}$ case, for example, $90 \%$ of the freight cars which gave rise to the tax were employed in interstate commerce) than on intrastate activity generally. And in the most recent case the

86. Nashville, C. \& St. L. Ry. v. Browning, 310 U.S. 362 (1940); Wells, Fargo \& Co. v. Nevada, 248 U.S. 165 (1918); Adams Express Co. v. Ohio State Auditor, 165 U.S. 194, 166 U.S. 185 (1897) ; Western Union Tel. Co. v. Taggart, 163 U.S. 1 (1896); Cleveland, C.C. \& St. L. Ry. v. Backus, 154 U.S. 439 (1894). (1897).

87. Adams Express Co. v. Ohio State Auditor, 165 U.S. 194, 166 U.S. 185

88. See Powell, Indirect Encroachment on Federal Authority by the Taxing Powers of the States. V., 32 Harv. L. Rev. 234, 263 (1919).

89. It should be added, of course, that the cases do not seem to have been argued on this ground. Ibid.

90. Illinois Central R.R. v. Minnesota, 309 U.S. 157 (1940); Great Northern Ry. v. Minnesota, 278 U.S. 503 (1929); Cudahy Packing Co. v. Minnesota, 246 U.S. 450 (1918); U.S. Express Co. v. Minnesota, 223 U.S. 335 (1912). See Powell, Indirect Encroachment on Federal Authority by the Taxing Powers of the States. VI., 32 HARV. L. REv. 374, 399 (1919).

91. Cudahy Packing Co. v. Minnesota, 246 U.S. 450, 456 (1918).

92. Id. at 452 . 
Court said that such a tax need have only "a fair relation to the property employed in the state," ${ }^{93}$ a standard which fails to suggest the need for equivalency with the tax burden on other types of property.

The comparatively recent case of Nashville, Chattanooga $\&$ St. Louis Ry. v. Browning ${ }^{94}$ demonstrates that in the eyes of the Court the equal protection policy in favor of permitting broad legislative classification completely outweighs any possibility of discrimination against interstate commerce inherent in singling out predominantly interstate types of businesses for special treatment. In that case the assessment of the property of a railroad company was challenged. Under the Tennessee taxing scheme, all property of public service corporations was assessed by the Railroad and Public Utilities Commission, all other property by the county assessors. The railroad contended that as a matter of practice the county assessors systematically valued property at far less than its full worth while utility and railroad properties were assessed at full value. The Court, in a unanimous opinion, sustained the tax. Without even considering the possibility of practical discrimination against interstate commerce, the Court restated the broad policy in favor of legislative classification for tax purposes, and concluded: "Since, so far as the Federal Constitution is concerned, a state can put railroad property into one pigeonhole and other property into another, the only question relevant for us is whether the state has done so." 95

Admitting that the problem of discrimination exists in special property tax classifications of the kind just discussed, should we now say that the cases have been wrongly decided? A flat answer cannot be given. Public service corporations in general, businesses such as the railroad and telegraph businesses with their lines of trackage or poles and wires extending through many states, are different from other kinds of concerns. They cannot be realistically assessed by county assessors. There are many legitimate reasons for singling them out for special tax treatment which do not necessarily involve attempts by the states to secure more than their fair share from the interstate enterprise. And, as Professor Powell once said in discussing this problem: "96 "A court cannot insist on an ideal system of state taxation, if such a thing can exist outside the minds of the doctrinaire. A rough approximation to fair treatment of interstate commerce is all that can reasonably be required." But on the other hand such

93. Illinois Central R.R. v. Minnesota, 309 U.S. 157, 164 (1940).

94. 310 U.S. 362 (1940).

95. $I d$ at 369.

96. Powell, Indirect Encroachment on Federal Anthority by the Taxing Powers of the States. V., 32 Harv. L. Rev. 234, 264 (1919). 
forms of classification may lend themselves to serious discriminations against interstate commerce. In many states the amount which would be extracted from out-of-state interests by a special tax on railroads, for example, might so far exceed the burden on local shippers and consumers as to tempt the legislature into imposing such a tax. ${ }^{97}$ The principal difficulty with the cases in this field, then, has been, as suggested earlier, that the Court has failed to see this discriminatory possibility. Its frank recognition by the Court might not result in a different decision in cases such as those which have come before it, but it could well serve as a warning to the states not to push too far the imposition of special property tax burdens on predominantly interstate businesses.

Goods in Transit. The rules, both commerce and due process, governing the taxation of goods in transit in interstate commerce also have long been settled. Goods within the state on tax day are taxable if the interstate journey has not yet commenced, or has been sufficiently interrupted, or has ended; but if the journey is in progress they are completely free from taxation. ${ }^{98}$ These rules do not, of course, make complete sense from a substantive commerce clause point of view. The complete exemption of goods in transit is at least as likely (perhaps more likely since shippers control shipment dates) to result in complete freedom from taxation for the year as the rule of taxation would be to result in double taxation. And should the tax day in the state of origin fall before the transit started and in the state of destination after it ended, the resultant double taxation would be just as burdensome on commerce as if the two taxes had fallen while the goods were actually moving. But the chief fault here lies in the use of an unapportionable tax day system of property taxation for movables, and there seems no reason for upsetting the long settled tax practices in this field. ${ }^{99}$

\section{B. Gross Receipts Taxes}

The largest single source of state revenue in 1951 was general sales and gross receipts taxes which accounted for approximately one-

97. And as was pointed out in the first section of this article the economic effect of taxes upon transportation and communication agencies is so diffused as to make difficult a realistic assessment of benefits and burdens to a state from a particular tax.

98. The earlier cases are cited and discussed in Minnesota v. Blasius, 290 U.S. 1 (1933). See also the discussion in Independent Warehouses, Inc. v. Scheele, 331 U.S. 70 (1947) (a license tax case); Von Hamm-Young Co. v. San Francisco, 29 Cal.2d 798, 178 P.2d 745 (1947).

99. See the detailed analysis in Powell, Taxation of Things in Transit, 7 VA. L. REv. 167, 245 and 497 (1920-21). 
fifth of all state tax collections. ${ }^{100}$ The combination of general gross receipts taxes and selective gross receipts taxes (on such items as tobacco and gasoline) produced approximately three-fifths of all state revenues. ${ }^{101}$ Sales taxes are also a rapidly growing source of revenue for municipalities. ${ }^{102}$

A wide variety of gross receipts taxes are imposed by the states, but only a few of the more common ones will be discussed here. Nearly every state imposes taxes measured by gross receipts on some or all types of public utilities. ${ }^{103}$ In most states these taxes are special taxes on public utilities and not part of a broader scheme of gross receipts taxation. Thirty-one states impose general sales taxes and all but three of these states have compensating use taxes. ${ }^{104}$ Three states impose a tax at varying rates upon the gross income from a wide variety of businesses or occupations, ${ }^{105}$ and two states impose such a tax upon substantially all businesses. ${ }^{106}$ Indiana alone has a tax upon gross income (including personal as well as business income) from all sources within the state. ${ }^{107}$

The early cases of state taxes upon gross receipts from interstate commerce which came before the Court dealt largely with special taxes on transportation and communication companies. With few exceptions ${ }^{108}$ these taxes were held invalid. ${ }^{100}$ By the opening years of the

100. U.S. Bureau of the Census, State Tax Collecrions IN 19512 (State Finances: 1951, No. 4).

101. Ibid.

102. See Roesken, Recent State Tax Trends, 30 TAxes 9, 10 (1952), reporting that approximately 150 municipalities in California have sales taxes but that there are comparatively few in other states. The most important municipal sales tax is that in New York City.

103. CCH, TAX Systems 262 et seq. (13th ed. 1952).

104. Roesken, Recent State Tax Trends, 30 Taxes 9, 10 (1952); CCH, Tax SxSTEMS 257 (13th ed. 1952).

105. Arizona, Mississippi, New Mexico. Id. at 257, 259.

106. Washington, West Virginia. New York City has a similar tax. Id. at 261.

107. Id. at 258; Black, The Indiana Gross Income Tax (1950).

108. In State Tax on Railway Gross Receipts, 82 U.S. 284 (1873), a Pennsylvania gross receipts tax applied to railroad, canal and transportation companies incorporated under the law of Pennsylvania was held valid, partly upon the theory that the state which created the corporation could tax its franchise in any way it saw fit. In Maine v. Grand Trunk Ry., 142 U.S. 217 (1891), a gross receipts tax for the privilege of doing railroad business in the state was upheld on the theory that a state, having the power to exclude a foreign corporation, also had the power to impose any conditions it saw fit upon the admission of such a corporation to do business within the state. The theory underlying the Grand Trunk case was finally repudiated by the Court in Western Union Tel. Co. v. Kansas, 216 U.S. 1 (1910). The story of these cases is told in Powell, Indirect Encroachment on Federal Authority by the Taxing Powers of the State. II., 31 Harv. L. REv. 572, 576 (1918). Cf. Railroad Co. v. Maryland, 88 U.S. 456 (1875) ; Ficklen v. Shelby County Taxing Dist., 145 U.S. 1 (1892) (tax on brokers).

109. Fargo v. Michigan, 121 U.S. 230 (1887) ; Philadelphia \& S. Steamship Co. v. Pennsylvania, 122 U.S. 326 (1887) ; Ratterman v. Western Union Tel. Co., 127 U.S. 411 (1888). 
present century the rule was settled that any tax measured by gross receipts which could not be said to be in lieu of property taxes ${ }^{110}$ was invalid to the extent that gross receipts from interstate commerce ${ }^{111}$ were included, even though imposed upon a local subject and properly allocated. ${ }^{112}$ In this respect a distinction was drawn between net income and gross receipts taxes. The former were held to affect interstate commerce only indirectly because the tax does not arise unless a profit is shown and cannot be large unless the profit is large. ${ }^{113}$ The latter were held to impose "a direct and immediate burden" upon commerce because they were imposed without reference to the profitability of the business and hence might "so diminish the profit as to impede or discourage the conduct of the commerce." 114

While the Court thus talked in terms of the extent of the impact of a gross receipts tax upon commerce, it is probable that its adverse reaction to such taxes stemmed from their special character. Ad valorem property taxes, which also applied without regard to the profitability of a business and which might so diminsh the profit as to discourage the conduct of a business, were, as we have seen, upheld. They were (with few exceptions) general; everyone paid them, and the normal political limitations served to control the amount. The gross receipts taxes which came before the Court, on the other hand, were designed to extract heavy tax revenues from particular businesses which were largely interstate in character, and did present a substantive danger that interstate commerce would be called upon to bear special burdens.

More recently the Court has modified its position with respect to gross receipts taxes as applied to transportation businesses. In one case a tax on gross receipts was held properly applicable to an inter-

110. Cases cited supra note 90. See also Wisconsin \& Michigan Ry. v. Powers, 191 U.S. 379, 387 (1903) ; Galveston, Harrisburg \& San Antonio Ry. v. Texas, 210 U.S. 217, 226 (1908).

111. In some cases the Court avoided the rule against the imposition of taxes on gross receipts from interstate commerce by terming intrastate what was essentially interstate business. New York v. Sohmer, 235 U..S. 549 (1915) (transporation between two points in one state over a line running part way in another state); Lehigh Valley R.R. v. Pennsylvania, 145 U.S. 192 (1892) (same); New York v. Knight, 192 U.S. 21 (1904) (cab service between interstate ferry and homes of patrons).

112. Galveston, Harrisburg \& San Antonio Ry. v. Texas, 210 U.S. 217 (1908); Meyer v. Wells, Fargo \& Co., 223 U.S. 298 (1912). The early development is discussed in detail in Powell, State Income Taxes and the Commerce Clause, 31 YALE L.J. 799 (1922). Later cases applying the same rule include New Jersey Bell Tel. Co. v. State Board of Taxes, 280 U.S. 338 (1930) ; Fisher's Blend Station v. State Tax Comm'n, 297 U.S. 650 (1936); Puget Sound Steve. Co. v. State Tax' Comm'n, 302 U.S. 90 (1937) ; Joseph v. Carter \& Weekes Steve. Co., 330 U.S. 422 (1947).

113. United States Glue Co. v. Oak Creek, 247 U.S. 321, 328 (1918).

114. Id. at 329. 
state bus company on a basis of a mileage allocation. ${ }^{115}$ In another a franchise tax measured by gross receipts allocated on a mileage basis was upheld as applied to a railroad doing both interstate and intrastate business. ${ }^{116}$ Earlier, however, the New York City general gross recepits tax was held invalid as applied to the income of a stevedoring company derived from loading and unloading ships engaged in interstate commerce even though all the activities giving rise to the income took place within the city. ${ }^{117}$ And of course, the rule of the Spector case forbids any gross receipts tax in the form of a franchise or privilege $\operatorname{tax}$ where the company concerned does a wholly interstate business. ${ }^{118}$

With respect to gross receipts taxes bearing upon the production and distribution of goods, however, the Court has continued to require the states to segregate intrastate and interstate gross receipts and to forbid taxation of the latter. Two types of taxes are involved here: those imposed upon retailing and those imposed earlier in the process of production and distribution. Take first the sales and use taxes which are imposed on retailing. ${ }^{119}$ With respect to the sales tax, the line was drawn in the early cases between interstate and intrastate sales. ${ }^{120}$ Where, for example, a local merchant or peddler made a sale of goods from a stock within the state, the sale was held to be an intrastate sale and fully taxable even though the goods sold had come

115. Central Greyhound Lines v. Mealey, 334 U.S. 653 (1948); see Barrett, supra note 6 at 524 .

116. Canton R.R. v. Rogan, 340 U.S. 511, 515 (1951). Mr. Justice Douglas, speaking for a majority of six, stated: "It is settled that a non-discriminatory gross receipts tax on an interstate enterprise may be sustained if fairly apportioned to the business done within the taxing state ... and not reaching any activities carried on beyond the borders of the state. Where transportation is concerned, an apportionment according to the mileage within the state is an approved method." Id. at 515. Justices Jackson and Frankfurter joined in an opinion "reserving judgment." Mr. Chief Justice Vinson did not participate. Although the Canton case was not referred to in the Spector Motor case decided shortly after, the cases are apparently distinguishable on the ground that the railroad in the Canton case did some local business. But cf. Memphis Steam Laundry Cleaner, Inc. v. Stone, 342 U.S. 389 (1952).

117. Joseph y. Carter \& Weekes Steve. Co., 330 U.S. 422 (1947). See Barrett, supra note 6 at 522 .

118. Both Memphis Natural Gas Co. v. Stone, 335 U.S. 80 (1948) and Interstate Oi1 Pipe Line Co. v. Stone, 337 U.S. 662 (1949), see discussion supra note 9, would appear to be overruled by the Spector Motor case. However, the Court in the Spector Motor case cited the Memphis Gas case for the proposition that a gross receipts tax may be upheld where the taxpayer's business activity is "local in nature" and the Interstate Oil Pipe Line case for the proposition that where a taxpayer does some intrastate business a privilege tax may be imposed and measured by both intrastate and interstate business. 340 U.S. at 610 .

119. Two types of sales taxes are common. One is a tax on the sales transaction itself, collected by the retailer. The other is an excise for the privilege of engaging in the business of selling, measured by the gross receipts from sales-a retailers occupation tax. Blakey, Sales ANd OTHER EXCISES 5 (1945).

120. For a discussion of the cases, see Lockhart, The Sales Tax in Interstate Commerce, 52 HaRv. L. Rev. 617 (1939); Powell, New Light on Gross Receipts Taxes: The Bervind-White Case, 53 Harv. L. REv. 909 (1940); Johnson, State Sales Taxes and the Commerce Clause, 24 CALIF. L. Rev. 155 (1936); Johnson, Multi-State Taxation of Interstate Sales, 27 CALIF. L. REv. 549 (1939). 
from outside the state. ${ }^{121}$ But where a sale resulted from orders solicited by a drummer within the state, forwarded to the home office in another state for acceptance, and filled by direct shipment to the buyer, the sale was an interstate sale and assumed to be completely immune from the tax. ${ }^{122}$ Furthermore, it was assumed that sales of this latter type would also be exempt from any sales tax imposed by the state in which the seller was located. ${ }^{123}$

This pattern of decision made it difficult for states to impose general sales taxes, since the result was to place local retailers at a competitive disadvantage with respect to out-of-state retailers who could sell to customers within the state free from the tax. As a result the states, borrowing from the gasoline tax experience, ${ }^{124}$ devised the compensating use tax to reach goods which came into the state as a result of nontaxable sales. ${ }^{125}$ This tax also had the advantage, in cases of substantial purchases which could be detected, of preventing local purchasers from evading tax by taking delivery of articles in other states and then bringing them home for use. The Court has upheld the application of the general use tax in all the cases which have come before it on the theory that the tax is upon the local or intrastate use and is not upon the interstate sale. ${ }^{126}$ Charges of discrimination against interstate commerce have been answered by pointing to the fact that while goods acquired as the result of intrastate sales were not subject to the use tax they were subjected to a sales tax of

121. Woodruff v. Parham, 75 U.S. 123 (1869); Hinson v. Lott, 75 U.S. 148 (1869); Banker Bros. Co. v. Pennsylvania, 222 U.S. 210 (1911).

122. The early cases involved fixed sum license taxes imposed upon drummers. See, e.g., Robbins v. Shelby County Taxing Dist., 120 U.S. 489 (1887) ; Lockhart, supra note 120 at 620 . The Court assumed, however, that the same rule would apply to a sales tax on the sales. See Sonneborn Bros. v. Cureton, 262 U.S. 506, 515 (1923); Lockhart, supra note 120 at 618 . The first actual decision to this effect was in McLeod v. J.E. Dilworth Co., 322 U.S. 327 (1944).

123. See, e.g., Crew Levick Co. v. Pennsylvania, 245 U.S. 292, 295 (1917) (tax on wholesaler shipping goods in foreign commerce).

124. Several cases upheld the application of a use tax to gasoline even though it came into the state as the result of an interstate sale or was to be used to propel vehicles engaged in interstate commerce. See, e.g., Bowman v. Continental Oil Co., 256 U.S. 642 (1921); Gregg Dyeing Co. v. Query, 286 U.S. 472 (1932) ; Nashville, C. \& St. L. Ry. v. Wallace, 288 U.S. 249 (1933). But cf. Helson v. Kentucky, 279 U.S. 245 (1929) ; Bingaman v. Golden Eagle West. Lines, Inc., 297 U..S. 626 (1936).

125. The leading case is Henneford v. Silas Mason Co., 300 U.S. 577 (1937). See also Traynor, The California Use Tax, 24 CaLIF. L. REv. 175 (1936) ; Warren \& Schlesinger, Sales and Use Taxes: Interstate Commerce Pays Its Way, 38 CoL. L. REV. 49 (1938) ; BLAKEY, op. cit. supra note 119, at 18.

126. In addition to the Silas Mason case the principal decisions have been: Felt \& Tarrant Mfg. Co. v. Gallagher, 306 U.S. 62 (1939) ; Southern Pacific Co. v. Gallagher, 306 U.S. 167 (1939); Pacific Tel. \& Tel. Co. v. Gallagher, 306 U.S. 182 (1939) ; Nelson v. Sears, Roebuck \& Co., 312 U.S. 359 (1941); General Trading Co. v. State Tax Comm'n, 322 U.S. 335 (1944). In the Silas Mason case the Court said: "The tax is not upon the operations of interstate commerce, but upon the privilege of use after commerce is at an end." 300 U.S. at 582. 
equal amount. ${ }^{127}$ The Court has not yet been required to decide whether the commerce clause forbids a state to impose the use tax on goods where delivery was taken in another state and a sales tax paid in that state upon the sale. It has indicated that a use tax which gives a credit for sales tax paid in the other state can validly be applied in such a situation. ${ }^{128}$

Although the sales and use tax combination enables states to tax substantially all sales with respect to which they can get due process jurisdiction over the seller for purposes of collection, there has been considerable pressure to expand the permitted coverage of the sales tax to take care of the few situations where the use tax cannot be employed. ${ }^{129}$ The Court has responded in part to this pressure. For a time it was thought that McGoldrick v. Berwind-White Coal Mining Co. ${ }^{130}$ and companion cases ${ }^{131}$ in 1940 gave permission to the state of the market to tax even interstate sales. ${ }^{132}$ McLeod $v$. J. E. Dilworth $\mathrm{Co}^{133}$ in 1944 , however, demonstrated that at least in situations where a seller sent only drummers into a state the sales tax was invalid while General Trading Co. v. State Tax Comm'n ${ }^{134}$ decided at the same time, reaffirmed the applicability of the use tax in such a situation. More recently, in Norton Co. v. Department of Revenue ${ }^{135}$ the Court held

127. Henneford v. Silas Mason Co., 300 U.S. 577, 583 (1937).

128. In the Silas Mason case, the Court said: "We have not meant to imply by anything said in this opinion that allowance of a credit for other taxes paid to Washington made it mandatory that there should be a like allowance for taxes paid to other states. A state, for many purposes, is to be reckoned as a self-contained unit, which may frame its own system of burdens and exemptions without heeding systems elsewhere. If there are limits to that power, there is no need to mark them now. It will be time enough to mark them when a taxpayer paying in the state of origin is compelled to pay again in the state of destination. This statute by its framework avoids that possibility. The offsetting allowance has been conceded, whether the concession was necessary or not, and thus the system has been divested of any semblance of inequality or prejudice." Id. at 587.

129. E.g., sales to purchasers who for some reason are themselves exempt from tax. In California, e.g., banks and insurance companies are exempt from such excise taxes. Cal. REv. AND TAX C. $\$ \$ 12263,23182$ (Supp. 1947).

130. 309 U.S. 33 (1940).

131. McGoldrick v. Felt \& Tarrant Mfg. Co., 309 U.S. 70 (1940). See also Jagels, "A Fuel Corporation," v. Taylor, 309 U.S. 619 (1940) (per curiam opinion).

132. See Powell, New Light on Gross Receipts Taxes: The Berwind Case, 53 Harv. L. Rev. 909 (1940); Barrett, supra note 6 at 512.

133. 322 U.S. 327 (1944). See Barrett, supra note 6, at 516.

134. 322 U.S. 335 (1944). See Barrett, supra note 6 , at 515.

135. 340 U.S. 534 (1951). The tax involved here was an Illinois retailers occupation tax. In distinguishing $\dot{M} c$ Leod $v$. Dilworth, the Court said: "Where a corporation chooses to stay at home in all respects except to send abroad advertising or drummers to solicit orders which are sent directly to the home office for acceptance, filling, and delivery back to the buyer, it is obvious that the State of the buyer has no local grip on the seller. Unless some local incident occurs sufficient to bring the transaction within its taxing power, the vendor is not taxable. ... Of course, a state imposing a sales or use tax can more easily meet this burden, because the impact of those taxes is on the local buyer or user. Cases involving them are not controlling here, for this tax falls on the vendor. But when, as here, the corporation has gone into the State to do local business by state permission and has submitted itself to the 
that where a concern maintains a local selling branch within the state any orders channeled through that branch or shipments delivered by it may be subject to tax even though the sales involved are technically interstate in character. Only orders sent directly by the customer to the out-of-state factory and filled by shipment directly to the customer were held immune from the tax.

With respect to the second class of taxes, those imposed earlier in the process of production and distribution of goods, the Court has been more generous with the states. Special taxes upon production (severance, mining, manufacturing, generation of power, etc.) have been sustained even though the goods produced have gone immediately into interstate commerce. ${ }^{136}$ Thus, in the leading case of Oliver Iron Mining Co. v. Lord, ${ }^{137}$ a Minnesota tax of $6 \%$ of the value of all ore mined in the state was upheld against a showing that $98 \%$ of the ore was mined to fill contracts with out-of-state purchasers and was immediately shipped in interstate commerce. In American $M f g$. Co. $v$. St. Louis, ${ }^{138}$ a municipal license tax on manufacturing measured by gross proceeds from sales of the goods manufactured was upheld as applied to the proceeds from goods manufactured in St. Louis, sent to warehouses outside the state, and there sold to out-of-state purchasers. In upholding taxes of this character the Court has relied on the theory that production is intrastate rather than interstate in character and hence taxes upon production have only an indirect effect upon interstate commerce. ${ }^{139}$

taxing power of the State, it can avoid taxation on some Illinois sales only by showing that particular transactions are dissociated from the local business and interstate in nature." Id. at 537. Mr. Justice Reed dissented from the decision of the Court that the tax could be applied to sales consummated as the result of orders taken by the Illinois branch office, forwarded to Massachusetts for acceptance, and shipped directly from Massachusetts to the Illinois buyer. Justices Clark, Black, and Douglas dissented from the decision that the tax could not be applied to sales consummated as the result of orders sent directly by the buyer to the Massachusetts office and filled by shipment directly to the buyer.

136. Hope Natural Gas Co. v. Hall, 274 U.S. 284 (1927) (privilege tax measured by value of natural gas produced as shown by gross receipts from sales of gas); Lacoste v. Dep't of Conservation, 263 U.S. 545 (1924) (severance tax of $2 \%$ of the value of all skins and hides taken from wild animals in the state); Oliver Iron Mining Co. v. Lord, 262 U.S. 172 (1923) (occupation tax equal to $6 \%$ of the value of ore mined in the state); Heisler v. Thomas Colliery Co., 260 U.S. 245 (1922). (tax of $1 \mathrm{z} \%$ of the value of anthracite coal when prepared for market); American Mfg. Co. v. St. Louis, 250 U.S. 459 (1919) (city license tax on manufacturing measured by gross sales). Cf. Department of Treasury v. Ingram-Richardson Mfg. Co., 313 U.S. 252 (1941) ; Toomer v. Witsell, 334 U.S. 385 (1948) (excise tax on shrimp); Utah Power \& Light Co. v. Pfost, 286 U.S. 165 (excise tax on generation of electric power). See Note, Natural Resource Taxation and The Commerce Clause, 30 Texas L. REv. 96 (1951).

137. 262 U.S. 172 (1923).

138. 250 U.S. 459 (1919).

139. See id. at 464. 
In this area of state taxation, great importance is given to the label affixed by the state to the tax. ${ }^{140}$ In J. D. Adams Mfg. Co. $v$. Storen, ${ }^{141}$ for example, the Indiana general gross income tax was held invalid as applied to the gross income from an Indiana corporation which manufactured road machinery in Indiana and sold $80 \%$ of its products to customers in other states and foreign countries upon orders taken subject to approval at the home office. The Court distinguished the American Mfg. Co. case on the ground that there the tax was on the privilege of manufacturing-a local activity-whereas in the Adams case the tax was on the gross sales which were themselves in interstate commerce. The Court did suggest that the tax in the Adams case would have been upheld if apportioned, but did not suggest by what means the apportionment should be made.

The Court has had only limited opportunities to deal with gross receipts taxes upon wholesalers and other distributors operating between production and retailing. There are dicta in two early cases to the effect that gross proceeds taxes on wholesalers are invalid to the extent that proceeds from sales which are consummated by delivery to customers in other states are taxed. ${ }^{142}$ More recently the Washington business activities tax measured by gross proceeds was held invalid as applied to the entire revenue of a concern which marketed Washington-grown fruit in other states for a fixed return per box of fruit sold, but with the suggestion that some form of apportionment would have saved the tax. ${ }^{143}$

In the field of gross receipts taxes, as elsewhere, more attention by the Court to the problems inherent in narrow classification would appear desirable. As noted above, special taxes on public utilities may in the case of predominantly interstate enterprises lend themselves to discrimination against interstate commerce. The same evil is inherent in privilege or occupation taxes applied to a wide variety of businesses where the rate varies with the particular type of business. Thus if oil and gas pipeline companies in a state do an almost wholly interstate business the normal political restraints on excessive taxation are minimized when the legislature is fixing the special rate by which gross receipts from such pipelines are to be taxed. Several recent cases decided by the Court involved taxes which might be subject to objec-

140. See Powell, State Production Taxes and the Commerce Clause, 12 CaLrF. L. REv. 17 (1923).

141. 304 U.S. 307 (1938). See Barrett, supra note 6, at 513.

142. See Crew Levick Co. v. Pennsylvania, 245 U.S. 292, 295 (1917) ; Sonneborn Bros. v. Cureton, 262 U.S. 506, 515 (1923).

143. Gwin, White \& Prince v. Henneford, Inc., 305 U.S. 434 (1939). 
tion on this score. ${ }^{144}$ Since the cases apparently were not argued on this point, however, it is not possible to tell whether interstate commerce was in fact subjected to discrimination in those cases.

Classification problems also arise in connection with special taxes on production. Where the goods produced flow predominantly to other states, the taxes levied fall more heavily upon extra-state interests than upon intra-state interests, with the consequent danger that a disproportionate share of state revenues will be sought from this source. Where the state has no natural monopoly on the goods produced, this danger is tempered by the fact that the state does not want to price itself out of a market. Where there is substantial use of the product within the producing state, local political restraints will operate to control the tax. But where the state has a substantial monopoly of goods which are necessities in other states (natural gas from Texas and a few other states, anthracite coal from Pennsylvania, etc.), there is little restraint upon the state. ${ }^{145}$ As Professor Powell put it: ${ }^{148}$ "When ... a state by imposing a tax on a selected enterprise reaps a revenue from citizens of other states and imposes no corresponding burden on its own citizens, the rapacity of the taxing state has no political or economic limits other than a cautious instinct not to kill or maim the goose that lays the golden eggs."

Whether the Court has been right or wrong in upholding the specific production taxes which have come before it cannot now be determined. Nor is it argued that all special taxes of this kind should be held invalid. The state which has unique natural resources has some special governmental obligations with respect to them and, perhaps, some equitable claim to obtaining special public as well as private revenues from their development. ${ }^{147}$ But the Court should recognize the dangers to commerce involved in production taxes and keep the door open to nullify them in the extreme cases where it is clear that commerce has been substantially burdened.

The most difficult problem with reference to gross receipts taxes is that of proper allocation. In the field of public utilities taxation, interstate commerce problems arise most often in connection with interstate transportation and communication companies. Mileage al-

144. See, e.g., Canton R.R. v. Rogan, 340 U.S. 511 (1951) (special tax on public utilities at varying rates); Interstate Oil Pipe Line Co. v. Stone, 337 U.S. 662 (1949) (privilege tax on selected occupations at varying rates); Central Greyhound Lines v. Mealey, 334 U.S. 653 (1948) (special tax on the gross receipts of public utilities). $C f$. the treatment of the discrimination point in Memphis Steam Laundry Cleaner, Inc. v. Stone, 342 U.S. 389 (1952).

145. See Federal, State, and Local Govermment Fiscal Relations, SEN. Doc. No. 69, 78th Cong., 1st Sess. 221 (1943).

146. Powell, State Production Taxes and the Commerce Clause, 12 CALIF. L. REv. 17, 21 (1923).

147. See id. at 23. 
location formulas, which have recently won Court approval in general terms, appear to be roughly satisfactory here and to present no problems substantially different from those involved in the field of property taxation.

In the application of gross receipts taxes to retail sales, however, there has been no attempt to impose or require general allocation formulas. Instead each sale has been treated as a unit, either fully taxable or fully exempt, as the case may be. Certainly where sales taxes as opposed to general gross income taxes are involved, such treatment of the allocation problem appears inevitable. Unfortunately, however, the Court's use of the distinction between intrastate and interstate sales as a basis for allocation has resulted in formal distinctions without substantive justification. Why should interstate sales be exempted from the sales tax only to fall prey to the use tax? Why should a sale negotiated through a drummer and followed by shipment direct to the buyer be exempt from sales tax while a sale negotiated through a branch office followed by a similar shipment directly to the buyer is taxable? In this field it would seem desirable for the Court to recognize frankly the pattern which has largely been worked out by the states themselves: Each state should be permitted to impose its sales tax upon all sales, regardless of the manner in which they are negotiated, which result in a delivery of goods to a buyer within the state. Conversely, states would be forbidden to impose a sales tax upon any sales, even of goods produced locally and sold by local retailers, where the goods are delivered to the buyer in another state. ${ }^{148}$ Furthermore, states should be permitted to impose a use tax upon goods when the purchaser has taken delivery in another state at least where credit is given for sales taxes paid in the state of delivery. ${ }^{149}$ General gross income taxes should be subject to the same limitations to the extent that they apply to retail operations. ${ }^{150}$ This pattern of

148. The arguments for taxation by the buyer's state only are elaborated in Snell, Sales Taxes and Interstate Commerce, 27 TAXEs 37, 47 (1949).

149. The question of whether states should be permitted to impose a use tax upon goods where the purchaser has taken delivery in another state without permitting a credit for taxes paid there is a difficult one. On the one hand, commerce is clearly put at a disadvantage if two taxes must be paid. But on the other hand, the administrative difficulties in checking to see if taxes actually have been paid in other states may be insuperable. See Traynor, supra note 24, at 184; and Powell, Neze Light ons Gross Receipts Taxes. The Berwind-White Case, 53 HARv. L. REv. 909, 931 (1940).

150. Where a general gross income tax is involved, it would be possible to apply a general allocation formula of the type used in connection with net income taxes. But since allocation in connection with the more widely used sales taxes is on the basis of the individual sale, uniformity demands the same type of allocation with respect to general gross income taxes. In cases arising under the Indiana tax the Court has approached the matter in both ways. In J.D. Adams Mfg. Co. v. Storen, 304 U.S. 307 (1938), the Court appeared to be thinking of the use of a general allocation 307 (1938), the Court apternational Harvester Co. v. Dept. of Treasury, 322 U.S. 340 (1944), however, it approved an allocation of the specific sales. 
decision would mean that in any particular market all goods would be subject to the same gross receipts tax burden upon selling operations; and with respect to such taxes interstate goods would be treated equally with intrastate goods.

To the extent that the states impose gross receipts taxes upon wholesaling operations, it would seem that the rules should be similar to those applied to retailing. Each state should be permitted to collect that tax on, and only on, the proceeds of all wholesale sales where delivery is made to the retailer within the state, regardless of the location of the seller.

Production taxes measured by gross receipts present different problems. If a manufacturer is taxed upon his entire gross receipts from all sales made within and without the state, the measure of the tax reflects both manufacturing and selling values. To the extent that it represents selling values, it duplicates in part the sales tax and, where sales are made outside the state, reflects in part values attributable to out of state activity. Perhaps here the fairest solution (if the administrative problem of valuation can be solved) is to require that, insofar as interstate sales are involved, production taxes shall be measured by the value of the goods when produced, rather than by sales price. ${ }^{151}$

But, it will be argued, to permit the application of gross receipts taxes to manufacturing as well as to retailing is to impose the risk of undue burdens on the interstate flow of goods. If a tax is paid on the full value of the goods as produced in one state and on the full sale value in another state, multiple burdens can be said to have resulted. The answer to this argument comes, I think, in an analysis which keeps separate the taxes imposed at various stages of the productive process. In any particular market, then, the goods will all bear the same tax upon retailing. Goods coming from one state may also have been subjected to a manufacturing tax. But local goods and goods from other states may have paid a similar tax, or they may have borne at least as heavy a tax burden in other forms, such as higher property taxes, license taxes or net income taxes. Competitive equality can never be assured. If the state of the market taxes all retail sales (local and interstate) at the same level and no other state is permitted to tax such sales, and if the state of origin of the goods

151. In Hope Natural Gas Co. v. Hall, 274 U.S. 284 (1927), the Court suggested such a limitation. However, American Mfg. Co. v. St. Louis, 250 U.S. 459 (1919), which permitted measure of the tax by sales price, has since been frequently cited by the Court with approval. See, e.g., Freeman v. Hewit, 329 U.S. 249, 255 (1946); Joseph v. Carter \& Weekes Steve. Co., 330 U.S. 422, 431 (1947) ; J.D. Adams MIfg. Co. v. Storen, 304 U.S. 307, 312 (1938); Western Live Stock v. Bureau of Revenue, 303 U..S. 250,257 (1938). 
taxes all producers (those who do only a local business and those selling in interstate commerce) equally, the Court will have given as much protection as possible under our federal system.

\section{Net Income Taxes}

Net income taxes, now one of the three principal sources of state revenue, ${ }^{152}$ have presented relatively few commerce clause problems. The first cases to come before the Court involved general taxes allocated to income arising within the state, and were sustained on the theory that a net income tax imposed only an "indirect and incidental" charge upon commerce. ${ }^{153}$ In all the subsequent cases the imposition of net income taxes has been upheld ${ }^{154}$ except where an attempt has been made to impose a franchise or other privilege tax measured by net income upon the income from a concern doing a wholly interstate business. ${ }^{155}$ Prior to the Spector case a clear line of distinction was drawn between taxes "on" net income, which could be applied even to the wholly interstate business, and privilege taxes measured by net income which could not be imposed on such a business. ${ }^{156}$ Since the opinion in Spector does not refer to the "on" net income cases, their continuing validity is now subject to at least some question. ${ }^{157}$

No serious problems of classification have arisen in connection with net income taxes. The most common form of classification is between the $\operatorname{tax}$ on individuals and on corporations. ${ }^{158}$ Some states impose graduated rates on individuals and a flat rate on corporations. Some impose the tax only on business corporations and exclude individuals. Other variations appear. But these classifications are so broad as to present no substantial danger of discrimination against interstate commerce. Whatever one may think of the wisdom of discrim-

152. U.S. Bureau of the Census, State Tax Collectrons in 1951 (State Finances 1951, No. 4) 3.

153. United States Glue Co. v. Oak Creek, 247 U.S. 321, 328 (1918); Shaffer v. Carter, 252 U.S. 37 (1920); Underwood Typewriter Co. v. Chamberlain, 254 U.S. 113 (1920).

154. Atlantic Coast Line R.R. v. Daughton, 262 U.S. 413 (1923); Matson Navigation Co. v. State Board of Equalization, 297 U.S. 441 (1936); Wisconsin v. Minnesota Min. \& Mfg. Co., 311 U.S. 452 (1940); Memphis Natural Gas Co v. Beeler, 315 U.S. 649 (1942); West Publishing Co. v. McColgan, 328 U.S. 823 (1946). 155. Alpha Portland Cement Co. v. Mass., 268 U.S. 203 (1925) ; Spector Motor Service, Inc. v. O'Connor, 340 U.S. 602 (1951).

156. Compare West Publishing Co. v. McColgan, 328 U.S. 823 (1946), with Alpha Portland Cement Co. v. Mass., 268 U.S. 203 (1925). The distinction is discussed in detail in the opinion of the California Supreme Court in West Publishing Co. v. McColgan, 27 Cal.2d 705, 166 P.2d 861 (1946).

157. See Clark, Interstate Commerce and a State's Right to Revemue: A Rejoinder, 30 TAXES 263 (1952); and cf. Cox, Interstate Commerce and a State's Right to Revenue, 30 TAXES 25 (1952).

158. CCH, TAX Systems 173 (12th ed. 1950). 
inating between incorporated and unincorporated business, no serious commerce clause objection can be made.

In this field the Court has been faced with some difficult decisions regarding the fairness of particular allocation formulas. ${ }^{150}$ The limitations of the judicial solution of the apportionment.problem are well illustrated by the net income tax cases. ${ }^{160}$ In only one type of case, however, has the Court suggested any limit on the general requirement of allocation. The due process clause has been interpreted to permit the taxation of residents and domestic corporations upon entire net income wherever earned. ${ }^{161}$ While the Court has yet to give full consideration to a case directly presenting the problem of a tax imposed upon the entire net income of a domestic corporation engaged in interstate commerce in more than one state, it has been assumed that such a tax would be valid. ${ }^{162}$ Whether as a matter of policy such taxation should continue to be permitted is a difficult question. In Grein, White \& Prince v. Henneford, Inc. ${ }^{163}$ the Court held invalid an unapportioned gross receipts tax as imposed upon a domestic corporation with an opinion discussing at length the burdensome consequences to commerce from such a tax. Certainly the net income tax imposes a similar burden, lesser perhaps only in degree of severity. Yet on the other hand, there are problems of state policy. So far as taxes on individuals are concerned, the principle of progressive taxation might be evaded if the entire income of residents could not be considered. Furthermore, there is the fear that much of the income earned in other states may for various practical reasons escape taxation anywhere if not taxed at home. With respect to corporations these local policies are not quite so strong, especially since corporation taxes are less frequently made progressive.

Further consideration of this problem by the Court may be long postponed since the trend is toward its elimination by voluntary state action. Many states now provide for allocation as to residents under their personal income taxes, and all but three or four states provide for such allocation as to domestic corporations under their corporate

159. E.g., Butler Bros. v. McColgan, 315 U.S. 501 (1942).

160. Altman \& KeEsLing, op. cit. supra note 45 , demonstrates the limitations in detail. See also Cox, Uniformity of State Income Taxation, 30 TAXes 184 (1952).

161. New York ex rel. Cohn v. Graves, 300 U.S. 308 (1937); Lawrence v. State Tax Comm'n, 286 U.S. 276 (1932).

162. Altman \& Keesling, op. cit. sipra note 45, at 30; cf. Rock Island Refining Co. v. Oklahoma Tax Comm'n, 322 U.S. 711 (1944) (per curian opinion dismissing appeal "for want of a substantial federal question"). In two commerce clause cases the application of a net income tax to domestic corporations was upheld without examination of the particular allocation formulas used. Matson Navigation Co. v. State Board of Equalization, 297 U.S. 441 (1936) ; United States Glue Co. v. Oak Creek, 247 U.S. 321 (1918).

163. 305 U.S. 434 (1939). 
income taxes. ${ }^{164}$ And most of those states which do not permit allocation provide some sort of credit for taxes paid in other states. ${ }^{165}$ However, the problem may be raised in a slightly different form by the recent changes in two or three states denying apportionment of corporate income by corporations which do not maintain a permanent or continuous place of business outside the state. ${ }^{188}$

\section{License, Privinege and Occupation Taxes}

Many of the early cases which came before the Court involved license, privilege, occupation and similar taxes. Certain specific taxes of this type have already been discussed, but treatment will be given here to a few problems common to taxes of this kind.

The first difficulty arises from the fact that the terminology of license and privilege taxes often suggests that the states are granting special privileges for which the taxes are payment and that failure to pay will result in denial of the license and exclusion from that particular type of business. ${ }^{167}$ The Court has made it clear since the earliest cases that the states have no power to exclude concerns from doing an interstate business. ${ }^{168}$ And the Court has gone further to hold that even though no attempt is made to exclude, such taxes are invalid because the federal government, and not the states, is the source of the privilege of engaging in interstate commerce. ${ }^{169}$ Thus the Court said in the Spector Motor case that by virtue of the commerce clause the federal government has "the exclusive power to tax the privilege to engage in interstate commerce." 170

A second difficulty arises from the fact that many of the license and privilege taxes are fixed-sum taxes. Taxes of this kind have always distressed the Court. They bear no relation to business done or profits earned and hence may easily be made prohibitive in charac-

164. See the chart in Altman \& KEEsLING, op. cit. supra note 45, at 15-18.

165. Id. at 204.

166. Roesken, Recent State Tax Trends, 30 TAxes 9, 13 (1952).

167. In one of the earliest cases in which the Court held a license tax invalid the statute provided for an injunction against carrying on the business without paying the tax. Moran v. New Orleans, 112 U.S. 69 (1884). In the important early case of Leloup v. Port of Mobile, 127 U.S. 640 (1888), a $\$ 225$ license fee was imposed on a telegraph company doing both interstate and intrastate business and a fine of from one to fifty dollars was imposed for each violation of the ordinance. The Court posed the problem: "Can a State prohibit such a company from doing such a business within its jurisdiction, unless it will pay a tax and procure a license for the privilege?" Id. at 645 . (1893).

168. See, e.g., cases cited supra note 167; Harman v. Chicago, 147 U.S. 396

169. E.g., Spector Motor Service, Inc. v. O'Connor, 340 U.S. 602 (1951) : Memphis Natural Gas Co.v. Stone, 335 U.S. 80, 88 (1948); Crutcher v. Kentucky, 141 U.S. 47 (1891); see Interstate Oil Pipe Line Co. v. Stone, 337 U.S. 662, 677 (1949) (dissent).

170. 340 U.S. at 608 ; see supra note 65 ; Memphis Steam Laundry Cleaner, Inc. v. Stone, 342 U.S. 389 (1952). 
ter. They are especially adapted, as the Court has realized, to excluding or hampering interstate business when the same flat sum tax is imposed, for example, upon the local merchant as upon the-out-ofstate vendor who may operate only episodically in the state. ${ }^{171}$

Finally, most taxes of this character have been special rather than general. Cities have imposed license taxes upon particular classes of businesses. State privilege taxes have been imposed upon selected enterprises. Most of the cases to come before the Court have been those where railroads ${ }^{172}$ or telegraph companies ${ }^{173}$ or ferry boats ${ }^{174}$ or peddlers ${ }^{175}$ or drummers ${ }^{176}$ have been singled out for special taxation which involves at least the possibility of discrimination against interstate commerce.

Instead of looking at these problems in terms of the economic impact of the taxes on commerce, however, the Court has dealt with them at a formal level. If the taxes have been imposed upon interstate commerce-for example, a flat sum license tax on the doing of telegraph business in the city where both interstate and intrastate business is done ${ }^{177}$ - they have been held invalid. If they have been imposed on intrastate business-for example, a flat sum license tax on the doing of intrastate telegraph business in the city ${ }^{178}$ - they have been sustained. This approach ${ }^{179}$ has been at best only a partial solution to

171. Memphis Steam Laundry Cleaner, Inc. v. Stone, 342 U.S. 389 (1952) ; Nippert v. Richmond, 327 U.S. 416 (1946); Best \& Co. v. Maxwell, 311 U.S. 454 (1940); Robbins v. Shelby County Taxing Dist., 120 U.S. 489 (1887); see McGoldrick v. Berwind-White Coal Min. Co., 309 U.S. 33, 55 (1940). cars)

172. E.g., Pickard v. Pullman Southern Car Co., 117 U.S. 34 (1886) (Pullman

173. E.g., Leloup v. Port of Mobile, 127 U.S. 640 (1888) ; Cooney v. Mountain States Tel. \& Tel. Co., 294 U.S. 384 (1935) (telephone instruments).

174. E.g., Sauit Ste. Marie v. International Transit Co., 234 U.S. 333 (1914).

175. E.g., Memphis Steam Laundry Cleaner, Inc. v. Stone, 342 U.S. 389 (1952) ; Caskey Baking Co. v. Virginia, 313 U.S. 117 (1941).

176. E.g., cases cited supra note 171 .

177. Leloup v. Port of Mobile, 127 U.S. 640 (1888) ( $\$ 225$ license fee on telegraph companies held invalid); cf. Cooney v. Mountain States Tel. \& Tel. Co., 294 U.S. 384 (1935) (tax on telephone instruments).

178. Postal Telegraph Cable Co. v. Charleston, 153 U.S. 692 (1894) ( $\$ 500$ license fee on the intrastate business of a telegraph company held valid).

179. The fullest recent statement of the traditional approach is in Cooney $v$. Mountain States Tel. \& Tel. Co., 294 U.S. 384, 392 (1935): "There is no question that the State may require payment of an occupation tax from one engaged in both intrastate and interstate commerce. But a State cannot tax interstate commerce; it cannot lay a tax upon the business which constitutes such commerce or the privilege of engaging in it. And the fact that a portion of a business is intrastate and therefore taxable does not justify a tax either upon the interstate business or upon the whole business without discrimination. . . Where the tax is exacted from one doing both an interstate and intrastate business, it must appear that it is imposed solely on account of the latter; that the amount exacted is not increased because of the interstate business done; that one engaged exclusively in interstate commerce would not be subject to the tax; and that the one who is taxed could discontinue the intrastate business without also withdrawing from the interstate business." For a fuller citation of the early cases see Barrett, supra note 6, at 500. But cf. Chicago v. Willet Co., 344 U.S. 574 (1953) upholding an occupation tax on a trucker doing both an intrastate and interstate business stressing the fact that the taxpayer was a domestic corporation doing its principal business in the city. 
the problem. Businesses doing exclusively interstate commerce have been freed from state taxes of this type. But businesses doing both intrastate and interstate business (including most of the transportation and communication companies) have been subjected to the same exactions with the same dangers to interstate commerce. The burden of a $\$ 225$ a year municipal license tax is just as great when the subject of the tax is the doing of intrastate telegraph business within the city as when it is the doing of business generally in the city. ${ }^{180}$ The same classification problems with their possibilities of discrimination are present. True, as the Court has pointed out, ${ }^{181}$ such taxes can be avoided by ceasing to do the intrastate business. But this is rarely a practicable alternative. The Court has suggested that there are some limits in how far states can go in taxing the intrastate business of concerns which also do interstate business, ${ }^{182}$ but has rarely found them even when the intrastate business has been done at a loss. ${ }^{183}$ In the field of peddler and drummer taxation, the Court has painted a dark picture of the discriminatory impact on commerce of flat sum license fees upon drummers, ${ }^{184}$ but has turned a deaf ear to the pleas of peddlers on the ground that their business has been intrastate in character. ${ }^{185}$ Yet the consequences of the taxes in excluding commerce has been substantially as great in the one case as another, at least in those areas where the custom of the trade has made it impossible to shift to the drummer type of business.

The extent to which the Court has gone in this field in upholding state taxes which impose serious burdens on commerce and levy, in effect, special tolls on commerce flowing into other states is indicated

180. Compare the cases cited supra notes 177 and 178.

181. E.g., Pullman Co. v. Adams, 189 U.S. 420, 422 (1903) : "The company cannot complain of being taxed for the privilege of doing a local business which it is free to renounce." Cf. Pacific Tel. \& Tel. Co. v. Tax Comm'n, 297 U.S. 403 (1936).

182. The early cases are discussed in Powell, Indirect Encroachment on Federal Authority by the Taxing Powers of the States VII, 32 HARv. L. Rev. 634, 671-678 (1919).

183. There is a full discussion of the problem in Pacific Tel. \& Tel. Co. v. Tax Comm'n, 297 U.S. 403 (1936), where railroads and a telephone company challenged a tax on their local business on the basis of a showing that the local business was operated at a loss and that practical considerations prevented abandoning such business. The Court said: "But no reason has been suggested why a tax upon the local business should be held void . . . if, although conducted at an apparent loss, the corporation desires to continue it because of benefits present or prospective." Id. at 414. See also Postal Tel. Cable Co. v. Fremont, 255 U.S. 124 (1921); Williams v. Talladega, 226 U.S. 404 (1912).

184. See, e.g., the cases cited supra note 171 .

185. The most recent of many cases is Caskey Baking Co. v. Virginia, 313 U.S. 117 (1941); and cf. Memphis Steam Laundry Cleaner, Inc. v. Stone, 342 U.S. 389 (1952). 
by the recent case of Independent Warehouses $v$. Scheele. ${ }^{186}$ Independent Warehouses operated within Saddle River Township, New Jersey, a storage facility, where anthracite coal was brought from Pennsylvania mines and stored on intransit privileges until shipped on, chiefly to New York City consumers. This storage permitted movement of coal from the mines during the period of the year when production exceeded consumption and movement to consumers at the period when consumption exceeded production. The Township enacted an ordinance providing that "No person, firm or corporation shall conduct or carry on the business of the storage of personal property in a warehouse engaged in storing goods for hire . . . unless and until there shall be granted by the Township Committee of the Township of Saddle River in accordance with the terms of this ordinance, and shall be in force and effect, a license to conduct said business for the place and premises in or at which said business shall be conducted and carried on." For the license there was charged and collected in advance an annual fee of three-quarters of a cent for each square foot of ground in the Township where the business was carried on, and severe criminal penalties were provided for operating without the license. Here was a case with as much potential for discriminating against interstate commerce as any to come before the Court. So far as appeared (the dissent tells us) ${ }^{187}$ Independent Warehouses was the only concern affected by this special tax. Since the tax would ultimately be passed on to consumers of the coal in other states, the Township could levy a tax of any amount without economic impact upon its own residents. Mr. Justice Jackson in dissenting (with Mr. Chief Justice Vinson) commented:

"But here the ultimate burden of the tax falls on consumers in New York and elsewhere who have no representation in the government which lays the tax and fixes its amount. The authorities who fix the tax will never have to answer to those who pay it. ... If it is valid, I know of no reason why the community should bear any of its own tax burdens." 188

Yet the majority of the Court sustained the tax on the analogy to taxes dealing with ad valorem property taxes on goods. Within the precedents, the Court said, this was a sufficient interruption of the interstate transit to permit local property taxation. Therefore this tax was permissible. But the problem here was different from that

186. 331 U.S. 70 (1947).

187. Id at 95 .

188. Id. at 94 . 
in the property tax cases. In the latter cases the Court was dealing with a general nondiscriminatory tax in which the rate was necessarily limited by its impact on all property owners within the taxing jurisdiction. In such a situation the burden on interstate commerce would at least be limited by the local political influence of other property taxpayers. But here there was a special tax, freed of any substantial local limitations upon its amount. The fact that the storage of coal might within the precedents properly be determined an intrastate rather than an interstate activity had no bearing upon the substantive effect of this tax upon interstate commerce. That effect would have been not one whit more serious had the coal still been in the stream of commerce, yet there the Court would have held it invalid.

What should be the policy of the Court in this area of taxation? Granted that the line forbidding such taxes when imposed directly upon interstate commerce and permitting them when upon intrastate commerce or a local incident of interstate commerce ${ }^{189}$ does not make substantive sense, still it does relieve some commerce from the burden of special and potentially discriminatory state taxation. Can a line be drawn which does make better economic sense? It would be possible, of course, for the Court to say that no business which is engaged in interstate activity shall be subjected to special taxes of this character, even upon its intrastate business. In justification the Court could say that with the wide permission given to use general taxes measured by net and gross income there is no longer any necessity for inequitable special taxation. An intermediate position would be a rule that any special or flat sum license, privilege, or occupation tax will be viewed with suspicion where in practical effect it imposes a burden on interstate commerce. Thus a tax on the intrastate business of a railroad will be treated the same as a tax on its interstate business; a tax on a peddler the same as on a drummer. The Court could then make a practical examination of the situation, ${ }^{100}$ and sustain only those taxes where local administrative or other necessities appear to outweigh the possible impact on commerce flowing from actual operation of the tax. Such an approach would put a greater burden on the Court, but it seems the only realistic way to treat the problem at the judicial level.

189. The doctrine that a local incident of interstate commerce could serve as the subject of state privilege taxation was worked out principally in Coverdale v. ArkansasLouisiana Pipe Line Co., 303 U.S. 604 (1938) (license tax on gasoline engines used to operate compressors on interstate pipe line) and Memphis Natural Gas Co. v. Stone, 335 U.S. 80 (1948) (privilege tax on the local activities of maintaining and keeping in repair an interstate pipeline). See Barrett, supra note 6 , at 510 and 525 .

190. Such as that made in Nippert v. Richmond, 327 U.S. 416 (1946) ; Best \& Co. v. Maxwell, 311 U.S. 454 (1940). 


\section{E. Motor Vehicle Taxation}

Motor vehicle and motor fuel taxes combined represent the largest source of revenue in many states, often running as high as $50 \%$ of total state revenues. ${ }^{101}$ These taxes also present some of the most complex commerce clause tax problems, problems too complex to permit more than an outline here.

This area of state taxation is unique in that taxes are imposed according to the benefits received rather than to the ability to pay. ${ }^{\mathbf{1 0 2}}$ Through motor vehicle and fuel taxes the great bulk of the cost of maintaining roads is assessed directly upon the people who use those roads. These taxes do not represent merely a contribution to the general costs of government; they are treated as compensation for special services provided by the state.

Many difficult problems of allocation are raised for solution by the states. ${ }^{103}$ In the first place, a determination must be made of what proportion of road costs is properly assigned to general tax revenues to pay for the more generalized public benefits from the roads as opposed to that proportion to be assigned directly to users. In the second place, the user portion of the tax burden must be allocated fairly among the various classes of users. What proportion of the tax should fall upon automobiles? Upon trucks? Upon busses? What principles should govern this allocation? Amount of use? Wear and tear resulting from use? Benefits derived from the use? Should commercial operations bear a heavier load than private operations? Finally, within the various established classifications levies must be apportioned between interstate and intrastate users of the roads in such a manner as to meet objections based upon the commerce clause.

While there are wide variations in detail, a general pattern of state taxes in this field can be determined. ${ }^{104}$ The basic user taxes in all states are registration fees and fuel taxes. Registration fees normally vary according to the type or weight of the vehicle and not

191. CCH, Tax Systems 305, 306 (13th ed. 1952).

192. Zettel, Taxation for Highways in Califormia, 1 Nat. TAx. J. 207, 209 (1948); Note, Taxation of Interstate Motor Commerce, 100 U. of PA. L. REv. 71, 72 (1951).

193. These problems have been widely discussed. Among the recent literature are the following: Councr. of STate Governarents, Highway SafeTY-Motor Truck Regulation 112 (1950); Macdonald, A Factual Discussion of MotorTruCK Operation, Regulation, ANd Taxation 56-76 (Dep't of Commerce, Bureau of Public Roads, 1951); Nat. Ass'n Tax Administrators, A Practical Program to Improve Taxation of Interstate Highway Use (1952); National Highway Users Conference, The Ton-MIIE TAX (1950); Western Highway Institute, Highway Taxation Problems: A Synopsis (Tech. Bull. Series No. 3, 1950); Zettel, supra note 192; Note, Taxation of Interstate Motor Commerce, 100 U. of PA. L. REv. 71 (1951).

194. The taxes are summarized in Council of State Governments, op. cit. supra note 193 , at $105-110$. 
by the extent of use of the roads. Duplication of such fees is to a certain extent prevented by reciprocity provisions. Fuel taxes, imposed at varying rates per gallon, are usually a combination of sales and use taxation. In addition to these two types of taxes, a number of states impose additional taxes upon common carriers commonly measured by mileage, ton-mileage, or gross receipts. In most instances these special taxes are imposed by states which have a relatively small number of registered vehicles in proportion to the road system which they maintain and hence (through the operation of reciprocity provisions) are not able to rely upon the registration fee as an adequate revenue source. ${ }^{195}$

The commerce clause rules governing motor fuel taxation and the problems arising therefrom are substantially similar to those already discussed in connection with general sales and use taxes. ${ }^{196}$ But with respect to motor vehicle taxation the Supreme Court has devised special rules which have the effect of giving the states a much freer hand in obtaining revenue from interstate carriers than they enjoy in other fields of taxation. In the first two cases ${ }^{197}$ to come before it the Court upheld registration fees even where the proceeds exceeded the cost of regulation on the theory "that where a State at its own expense furnishes special facilities for the use of those engaged in commerce, interstate as well as domestic, it may exact compensation therefor." 198 In the third case the Court upheld a special tax on motor transportation companies as applied to a trucking company doing a wholly interstate business within the state:

"The highways are public property. . . . Users of them, although engaged exclusively in interstate commerce, may be required to contribute to their cost and upkeep. Common carriers for hire, who make the highways their place of business, may properly be charged an extra tax for such use." 199

Shortly thereafter the Court frankly recognized that it was applying special rules in this field:

195. Note, Taxation of Interstate Motor Commerce, 100 U. of PA. L. REv. 71, 80 (1951).

196. Among the recent cases are McCarroll v. Dixie Greyhound Lines, 309 U.S. 176 (1940); Bingaman v. Golden Eagle West. Lines, 297 U.S. 626 (1936); Wiloil Corp. v. Pennsylvania, 294 U.S. 169 (1935) ; Monamotor Oil Co. v. Johnson, 292 U.S. 86 (1934); Edelman v. Boeing Air Transport, 289 U.S. 249 (1933). The earlier cases are collected in Note, $80 \mathrm{~L}$. Ed. 931 (1936). The most difficult problems have arisen out of state attempts to assess a tax on fuel purchased outside the state but consumed inside as part of an interstate operation. See, e.g., the Dixie Greyhound and Golden Eagle cases, supra.

197. Hendrick v. Maryland, 235 U.S. 610 (1915); Kane v. New Jersey, 242 U.S. 160 (1916).

198. Hendrick v. Maryland, 235 U.S. 610,624 (1915).

199. Clark v. Poor, 274 U.S. 554, 557 (1927). 
"While a State may not lay a tax on the privilege of engaging in interstate commerce . . . it may impose even upon motor vehicles engaged exclusively in interstate commerce a charge, as compensation for the use of the public highways, which is a fair contribution to the cost of constructing and maintaining them and of regulating the traffic thereon. . . . As such a charge is a direct burden on interstate commerce, the tax cannot be sustained unless it appears affirmatively, in some way, that it is levied only as compensation for use of the highways or to defray the expense of regulating motor traffic." 200

The emphasis in most of the cases has been upon making a determination whether the tax has been imposed as a charge for the use of the highways or upon the privilege of engaging in interstate commerce. Express allocation of the proceeds of the tax to highway purposes has been held to indicate the compensatory nature of the tax. ${ }^{201}$ A statutory declaration that the tax is imposed to secure compensation for highway use has also been held sufficient even though the funds collected are not expressly allocated to highway use. ${ }^{202}$ More recently the Court has become concerned with the question of whether even taxes imposed as compensation do not also have to bear some relation to road use. In 1950 in Capitol Greyhound Lines v. Brice, ${ }^{203}$ the Court held that so long as the taxes imposed on carriers by the state do not exceed fair compensation for the use of the highways, the formula by which particular taxes are imposed is irrelevant. A titling tax of $2 \%$ upon the value of all vehicles purchased for use within the state was upheld even though the tax obviously bore no relation to the extent of road use. - The Court said that taxes upon motor carriers have been invalidated only upon finding that:

"(1) the tax discriminated against interstate commerce in favor of intrastate commerce; (2) the tax was imposed on the privilege of doing an interstate business as distinguished from a tax exacting contributions for road construction and maintenance or for administration of road laws; or (3) the amount of the tax exceeded fair compensation to the state." 204

This emphasis by the Court on compensation as the key to decision has tended to obscure the very difficult problems of possible dis-

200. Interstate Transit, Inc. v. Lindsey, 283 U.S. 183, 185 (1931).

201. E.g., Aero Mayflower Transit Co. v. Georgia Public Service Comm'n, 295 U.S. 285 (1935); and see Interstate Transit, Inc. v. Lindsey, 283 U.S. 183, 186 (1931).

202. E.g., Aero Mayflower Transit Co. v. Board of Railroad Comm'rs, 332 U.S. 495 (1947).

203. 339 U.S. 542 (1950). The dissenting opinion contains a useful appendix analyzing all of the prior cases dealing with motor vehicle taxation. Id. at 561. See also Bode v. Barrett, 344 U.S. 583 (1953).

204. Id. at 544. 
crimination against interstate commerce involved in many forms of motor vehicle taxes. Flat sum taxes or other taxes which do not in some way reflect the extent of road use are very apt to work a practical discrimination against interstate commerce. Take the Capitol Greyhound case as an example. Each of three interstate bus companies bought a new bus with the intent of using it on one of its routes within Maryland. The Maryland portions of the three routes were 9, 41, and 64 miles respectively. The titling taxes computed on the fair market value of each vehicle were $\$ 505, \$ 580$, and $\$ 372$, respectively. Thus one interstate company paid $\$ 505$ for 9 miles of route and another $\$ 372$ for 64 miles of route, yet an intrastate bus company for a similar charge might have operated a bus on a route hundreds of miles in length. All taxes of this character discriminate in favor of the constant user of roads within the state and, in the generality of instances, against the interstate operator whose use of the local roads is apt to be less extensive. In dealing with this problem the Court has said, in a case involving a flat sum tax:

"The fee is for the privilege of a use as extensive as the carrier wills that it shall be. There is nothing unreasonable or oppressive in a burden so imposed. ... One who receives a privilege without limit is not wronged by his own refusal to enjoy it as freely as he may." 205

This argument, however, overlooks the serious burden which would be placed upon interstate commerce by the multiplication of levies of that kind; the very nature of the business indicates that the interstate carrier will not make as full a use of the state highways as the intrastate carrier.

So far as registration fees are concerned, the general enactment by the states of reciprocity provisions has removed much of the potentialities for discrimination against commerce. ${ }^{206}$ The result of the Capitol Greyhound case, however, may well be to stimulate other special types of state taxes which are not subject to reciprocity.

The basic commerce clause problem is whether the state interest in securing revenues for the construction and maintenance of roads is so great as to permit taxes which has such potentialities for discrimination against interstate commerce. This question can be answered realistically, of course, only if one knows the feasibility of alternative methods of taxation. Can a mileage tax, for example, be devised which

205. Aero Mayflower Transit Co. v. Georgia Public Service Comm'n, 295 U.S. 285, 289 (1935).

206. See Note, Taxation of Interstate Motor Commerce, 100 U. of PA. L. Rev. 71,81 (1951). 
makes a rational allocation among all highway users and the collection of which is administratively feasible? Or can the states better solve the problem by increasing the fuel tax as a substitute for taxes unrelated to road use? What is the impact of each of these types of taxes on the local problem of securing a fair allocation of road costs among the various classes of users? Legislative rather than judicial solutions appear to be indicated in this complicated field. ${ }^{207}$ However, judicial recognition of the potentialities for discrimination against commerce involved in many motor vehicle taxes might at least stimulate the states to greater activity in their search for better alternatives.

\section{Legislative Solutions}

The states themselves have made some attempts to minimize burdens on interstate trade. Most states have either refrained from exercising their rights to tax residents and domestic corporations on their entire net income or else have allowed credits (frequently on a reciprocal basis) for such taxes paid elsewhere. ${ }^{208}$ Progress has also been made in securing the adoption of similar types of apportionment formulae in the net income tax field. ${ }^{209}$ Most states have reciprocity provisions which alleviate what would otherwise be an intolerable burden on interstate commerce from duplicated state registration fees on motor vehicles. ${ }^{210}$ It is unlikely, however, that any real uniformity will ever be attained by interstate cooperation. Many if not most states can always be counted on to take the position that "although uniformity is desirable it should be attained by the process of amending other state laws to conform with theirs."211 Efforts toward interstate cooperation should always be encouraged, but hope cannot be held out for any startling results.

Congressional action will be successful in proportion to the extent to which it interferes with state autonomy in the matter of taxation. The basic problem, as pointed out earlier, is the existence of independent taxing jurisdictions with no compulsion towards uniformity. All

207. The problem has recently been the subject of Congressional hearings: Hearings before Subcommittee on Domestic Land and Water Transportation of the Committee on Interstate and Foreign Commerce pursuant to $S$. Res. 50, 81st Cong., $2 \mathrm{~d}$ Sess. (1950). See Note, Tatation of Interstate Motor Commerce, 100 U. of PA. L. REV. 71 (1951).

208. See notes 164,165 supra.

209. Altaran \& KeEsling, op. cit. supra note 45. Tax administrators have themselves worked toward the use of uniform formulas whenever permitted by local statutes. A committee of the National Tax Association has worked on the development of a proposed uniform state income allocation tax law.

210. Note, Taxation of Interstate Motor Commerce, 100 U. of PA. L. REv. 71, 79 (1951).

211. AltMAN \& KeEsting, op. cit. supra note 45, at 248; Sutherland \& Vinciguerra, The Octroi and the Airplane, 32 CoRnell L.Q. 161, 169 (1946). 
the problems of barriers to free flow of trade from taxation would be eliminated by the simple expedient of superseding state taxes by a national tax or taxes, with the net revenue to be allocated back to the states. ${ }^{212}$ The savings in administrative costs alone would be tremendous and the cost of compliance factor for interstate business would be greatly lessened. But the barriers to the successful adoption of such a proposal are, at least for the foreseeable future, insuperable. The problems of allocation of revenue among the states would be complicated and difficult, and state autonomy would be at an end if the states were dependent on the federal government for revenue.

Various other proposals have been made for congressional action. ${ }^{213}$ Space will permit the discussion here, and that only briefly, of the one proposal which appears to have some possibility of adoption because it would minimize the worst state burdens on commerce without substantially impairing the independence of the states. This proposal was made with respect to net income taxes by Altman and Keesling in their book, Allocation of Income in State Taxation. In the discussion which follows, however, it has been generalized to suggest its application to other types of state taxes.

The essential idea is that uniformity in state taxation can be achieved with the least federal interference in local matters by legislation which prohibits the states from taxing interstate commerce or its avails except by certain specified forms of taxation.

To illustrate. With reference to property taxes a federal statute could provide that property used in the interstate transportation of goods and passengers-ships, railroad rolling stock, barges, airplanes, trucks, etc.-may not be taxed except by the application of allocation formulas spelled out in detail for each kind of property. Such a statute would insure that no more than $100 \%$ of the value of the property would be subject to taxation, and would also greatly simplify the accounting and reporting problems of the carriers. The statute could, if desired, go further and either ban special forms of property taxes on the property of interstate carriers or specify the formulas which

212. See discussions in Altman \& Keesling, op. cit. supra note 45, at 249; Snell, supra note 148, at 46; Sutherland \& Vinciguerra, supra note 211 , at 168.

213. Among the recent literature are the following: ALTMAN \& KEESLING, op. cit. supra note 45, ch. 12; Arditto, State and Local Taxation of Scheduled Local Airlines, 16 J. AIR L. \& CoM. 162 (1949); Browne, Federal-State Tax Coordination, 31 CORNELL L.Q. 182 (1945); Cox, Uniformity of State Income Taxation, 30 TAXES 184 (1952); Hellerstein \& Hennefeld, State Taxation in a National Economy, 54 HARv. L. Rev. 949 (1941) ; Saxe, Federal Control of the State Taxation of Airlines, 31 CoRNEl L.Q. 228 (1945); Schlesinger, Sales Taxes, Interstate Trade Barriers, and Congress: The Gulf Oil Case, 39 MrCH. L. Rev. 755 (1941) ; Snell, supra note 148; Sutherland \& Vinciguerra, supra note 211 ; Note, Tasation of Interstate Motor Commerce, 100 U. OF PA. I. REV. 71 (1951). 
could be used by the states in allocating unitary or system value for local taxation.

In the field of net income taxation the statute could forbid the taxation of income from interstate commerce except by a specified uniform allocation formula. It could also provide a uniform definition of residence. Or the statute could even go so far as to specify many other standards which the state statutes must meet as a condition of taxing the income from interstate business.

Other illustrations could be multiplied since this technique would appear adequate to solve the major interstate commerce problems involved in all forms of state taxes. One important advantage of this approach is that a gradual beginning could be made and coverage expanded as experience dictated. Thus, the first task might be to prescribe a uniform allocation formula for net income taxes. The experience gained there could be applied to prescribing allocation formulas for other forms of taxation.

The problems involved in the detailed drafting of such statutes will not be easy. ${ }^{214}$ Even the problem of working out a uniform allocation formula for net income taxation presents serious difficulties. For example, a formula that produces a large allocation to an industrial state may give such a small allocation to an agricultural state as to be unfair. If reasonable compromises of conflicting interests are to be made, extensive Congressional hearings and careful committee work will be essential. And in the end the problem may"prove too complicated for detailed statutory treatment, and may have to be turned over to an administrative agency governed by general statutory standards. ${ }^{215}$

214. See note 213, supra.

215. See Sutherland \& Vinciguerra, supra note 211. 